NBER WORKING PAPER SERIES

\title{
MITIGATING LONG-RUN HEALTH EFFECTS OF DROUGHT: EVIDENCE FROM SOUTH AFRICA
}

\author{
Taryn Dinkelman \\ Working Paper 19756 \\ http://www.nber.org/papers/w19756 \\ NATIONAL BUREAU OF ECONOMIC RESEARCH \\ 1050 Massachusetts Avenue \\ Cambridge, MA 02138 \\ December 2013
}

The paper benefited greatly from discussions with Douglas Almond, Patricia M. Anderson, Eric Edmonds and Erzo Luttmer as well as seminar participants at Columbia University, the Minneapolis and St. Louis Federal Reserve Banks, University of Cape Town, Washington University in St. Louis, the April 2012 BREAD Pre-Conference, the junior faculty lunch seminar at Dartmouth College and the NBER Summer Institute 2013. Support for this research was provided by the U.S. National Institute of Child Health and Human Development (Grant R03HD069060-01). All views expressed in the paper are my own and do not necessarily reflect the opinion or policy of the federal government, nor the views of the National Bureau of Economic Research.

NBER working papers are circulated for discussion and comment purposes. They have not been peerreviewed or been subject to the review by the NBER Board of Directors that accompanies official NBER publications.

(C) 2013 by Taryn Dinkelman. All rights reserved. Short sections of text, not to exceed two paragraphs, may be quoted without explicit permission provided that full credit, including $\odot$ notice, is given to the source. 
Mitigating Long-run Health Effects of Drought: Evidence from South Africa

Taryn Dinkelman

NBER Working Paper No. 19756

December 2013

JEL No. I15,J61,N37,O15

\begin{abstract}
$\underline{\text { ABSTRACT }}$
Drought is Africa's primary natural disaster and a pervasive source of income risk for poor households. This paper documents the long-run health effects of early life exposure to drought and investigates an important source of heterogeneity in these effects. Combining birth cohort variation in South African Census data with cross-sectional and temporal drought variation, I estimate long-run health impacts of drought exposure among Africans confined to homelands during apartheid. Drought exposure in early childhood significantly raises later life male disability rates by $4 \%$ and reduces cohort size. Among a subset of homelands - the TBVC areas - disability effects are double and negative cohort effects are significantly larger. I show that differences in spatial mobility restrictions that influence the extent of migrant networks across TBVC and non-TBVC areas contribute to this heterogeneity. Placebo checks show no differential disability impacts of drought exposure across TBVC and non-TBVC areas after the repeal of migration restrictions. The results show that although drought has significant long-run effects on health human capital, migrant networks in poor economies provide one channel through which families mitigate these negative impacts of local environmental shock.
\end{abstract}

Taryn Dinkelman

Department of Economics

H. Box 6106

Dartmouth College

Hanover, NH 03755

and NBER

taryn.1.dinkelman@ dartmouth.edu

An online appendix is available at:

http://www.nber.org/data-appendix/w19756 
Local environmental shocks are a pervasive source of income risk for many households in developing countries, and may have important short and long-term impacts on household welfare. Families typically rely on a variety of strategies to cope with such environmental risks, and a large development literature has focused on how insurance, savings and credit, or occupational and spatial mobility help households weather the immediate effects of local income shocks. ${ }^{2}$ In this paper, I turn attention to the long-run effects of coping with environmental income risk. I ask whether permanent labor migration of a family member - an important strategy for smoothing consumption in the face of local shocks - can help families mitigate the long-run health consequences of early life exposure to these shocks.

Specifically, I document the negative long-run health effects of childhood exposure to Africa's most prevalent natural disaster (Benson and Clay 2000): Drought. My analysis takes place in a context where some individuals face external restrictions on migration and cannot easily move away from localities experiencing drought. I investigate an important source of spatial heterogeneity in these long-run health effects, showing that drought had worse impacts in areas where spatial mobility was most restricted. I provide evidence that differences in exogenous migration restrictions influence the extent of migrant networks in different communities, and that these restrictions contribute to the heterogeneous health effects of early-life drought exposure.

My empirical analysis focuses on South Africa during the apartheid period, when a host of policies restricted African rights of movement, residence and employment in the modern sectors of the economy. Between 1948 and 1986 the South African government consigned the majority of Africans to live in predominantly rural and spatially isolated pockets of land called homelands. My analysis focuses on how individuals from these homelands experienced the longrun effects of drought exposure, both on average and differentially across subsets of homelands.

To estimate the main effects of childhood drought exposure in these homelands, I create and match measures of exogenous local drought in homeland districts to Census data on self-reported disabilities and district-level cohort size. I compare long-run health outcomes for cohorts born in

\footnotetext{
${ }^{2}$ See Besley (1995) and Townsend (1995) for reviews of some of this literature, and Rosenzweig and Stark (1989) for an important example of spatial mobility as insurance.
} 
drought years to those born in non-drought years, controlling for district and birth year fixed effects. The strength of this difference-in-differences research design is that I exploit many separate natural experiments for economic shocks identified by multiple local drought events across years and across districts. This minimizes concerns that results are driven by confounding shocks to health which are correlated with a drought event.

Establishing that childhood drought exposure has negative effects on later life health for the entire homeland sample is an important first step in the analysis. To better understand the channels through which families cope with this source of local income risk, I investigate heterogeneity in the health results exploiting legal differences in how spatial apartheid was applied in South Africa. Although no-one assigned to a homeland was ever entirely free to move about the country to look for work, some homeland areas faced greater mobility restrictions than others, and for more years. This meant that some families could more easily send out labor migrants to distant (often urban) locations not subject to the same sorts of local environmental risks. Section 1 provides an historical account of these mobility restrictions, describing how the oldest rural homelands - the TBVC states (Transkei, Boputhatswana, Venda and the Ciskei) faced the highest externally imposed barriers to permanent labor migration for the longest time. Indeed, the data show that TBVC and non-TBVC areas differ in cumulative outmigration flows in the years in which legal barriers to mobility were in place, but not after these laws were repealed.

Motivated by the history of differences in spatial mobility restrictions across homeland areas, I investigate heterogeneity in the long-run health effects of drought by adding a third difference to the regression analysis. Controlling for observed and unobservable differences between areas in non-drought years and for year fixed effects, I compare the health effects of local drought exposure in childhood across rural TBVC and non-TBVC homelands. The validity of this research design relies on the assumption of no contemporaneous health shocks coincident with drought that differ by TBVC and non-TBVC areas. Exploiting multiple drought events for identification again helps to shore up this assumption.

My main findings point towards large negative health effects of early childhood drought exposure. Cumulative drought exposure from the in utero period up to age four raises disability 
rates for Africans in all homelands by 0.1 percentage points (2.2\%). These effects are significantly larger, and more precisely estimated for males. Cumulative drought exposure raises disability rates among African males by about 0.2 percentage points or $4.5 \%$ and reduces male cohort size by 1.1 percentage points on average. These main effects of drought exposure in the entire homeland sample, as well as the larger effects estimated for males, are in line with estimates from the fetal and childhood origins of health literature. ${ }^{3}$ For most of the heterogeneity analysis, I restrict attention to the male sample.

In comparing the effects of drought exposure in TBVC relative to non-TBVC areas, I find that the negative effects of drought in early life are twice as large for males from TBVC areas. Cumulative drought exposure before age five in TBVC areas raises the probability of serious male disability by 0.2 percentage points, increasing overall disability prevalence by $8.8 \%$. Drought exposure in the birth year raises disability prevalence by 0.9 percentage points relative to males from non-TBVC areas: a 20\% increase compared with mean disability rates. Drought exposure also reduces male cohort size in TBVC areas by 2.6 percent, with some of this reduction driven by a negative fertility response among women with no education. These large, precisely estimated male disability and cohort size impacts of drought exposure among TBVC cohorts are particularly striking given the relative youthfulness of the sample (ages 10 to 48 ).

To interpret this heterogeneity in the male disability impacts of childhood drought exposure, I provide several checks to rule out confounding explanations as well as some additional evidence that differences in migration limitations across TBVC and non-TBVC areas contribute to this heterogeneity. First, my identification strategy controls for constant differences between TBVC and non-TBVC districts using district fixed effects. I also control for interactions of drought with

\footnotetext{
${ }^{3}$ See Almond and Currie (2011a, 2011b) for reviews of this literature. Martorell et al (1994) and Martorell (1999) provide a general discussion of the link between nutrition, disease and adult health. Recent empirical studies in the early-life health shocks literature include: Almond (2006) on exposure to the flu epidemic, Chen and Zhou (2007), Meng and Qian (2009), Lindeboom et al (2010) and van den Berg (2011) for analyses of early-life famine exposure, and Maccini and Yang (2009) and Aguilar and Vicarelli (2012) for exposure to floods, Banerjee, Duflo, PostelVinay and Watts (2010) for exposure to agricultural income shocks. Jensen (2000), Hoddinott and Kinsey (2001) and Alderman, Hoogeevan and Rossi (2009) analyze immediate and medium-term negative impacts of drought on child nutrition and schooling outcomes but do not consider how households may mitigate these effects. Almond and Mazumdar (2011) use data from several countries to estimate the negative effect on male disability rates of nutritional deprivation during Ramadan fasting.
} 
baseline district variables (historical population density, the suitability of land for maize production, and district remoteness) that may affect drought responses across areas. Results are robust and in some cases, strengthened, when controlling for these interaction terms.

Second, I estimate placebo regressions among male cohorts born since the repeal of legal migration restrictions in 1986 and before the end of apartheid in 1994. I show that the effects of being exposed to drought in early life are no longer different across TBVC and non-TBVC areas once legal restrictions on mobility fall away. This supports the idea that spatial mobility is an important channel through which households cope with drought.

Finally, I use Census data from the post-apartheid period to illustrate the mechanism through which labor migration helps families to cope with drought. Controlling for historical drought prevalence in each district and cross-sectional variation in the presence of any labor migrant attached to the household, I estimate that households in former homeland districts are between $13 \%$ and 16\% more likely to receive remittances in 1995 if there was a drought in their district in 1995. Importantly, remittance flows into households with migrant workers drive this effect. These remittance results provide direct evidence on why differential adult outmigration from homelands during apartheid was important for helping families cope with local income risk.

Although my research design is robust to a range of potential threats to validity, the data do not allow me to completely rule out every other potential channel through which households in TBVC areas were less able to cope with drought. The final section of the paper discusses other possible mechanisms through which TBVC and non-TBVC areas may have experienced drought differently. This discussion draws on prior research to highlight that migrant networks in former homeland areas are far more prevalent than other formal and informal risk coping strategies these areas. While I cannot estimate the marginal impact of labor migration on long-run health outcomes, the different pieces of evidence in this paper together suggest that spatial mobility is more than just a short-run risk-coping strategy. Labor migration provides additional benefits to households by mitigating the long-run health effects of local shocks to income.

My paper makes three main contributions. First, I add to the early-life health shocks literature by providing new evidence on the negative health impacts of a highly prevalent local environmental shock. I also provide some of the first empirical evidence that households may act to mitigate 
some of the negative effects of early-life health shocks. ${ }^{5}$ My analysis of spatial heterogeneity in these health effects of drought exposure suggests that migration is a specific mechanism through which families, responding to local shocks, can at least partially mitigate the impact of negative economic shocks on children.

Second, I extend the development literature on migration as insurance by showing that differential limits on spatial mobility contribute to heterogeneous effects of drought on disability and cohort size. By showing that remittances respond strongly to local drought and that these remittance flows occur primarily through existing migrant networks, I provide specific evidence on the mechanisms through which spatial mobility helps families mitigate the negative impacts of local drought. In contrast to other studies (Rosenzweig and Stark 1989, Jayachandran 2006, Yang and Choi 2007) that focus on the immediate and short-run consumption smoothing benefits of spatial mobility, my paper emphasizes how migration can insure against negative long-term effects of these economic shocks and protect human resources for economic growth. ${ }^{6}$ These results motivate an even larger insurance role for spatial mobility than the literature has previously emphasized.

Third, I exploit multiple sources of exogenous variation in local economic shocks and exogenous variation in mobility restrictions across areas to establish the long-term health effects of drought exposure and shed light on the migration channel. The South African case allows me to focus on mobility restrictions that are exogenous to the individual, thereby getting around some of the more difficult selection issues associated with comparing migration rates and remittance flows across space. This context presents a unique opportunity to investigate one specific channel through which barriers to spatial mobility impose long-run economic costs.

\footnotetext{
${ }^{5}$ Currie and Vogl (2013) suggest that how parents respond to early life health shocks is an important new area of research in the fetal and childhood origins of health literature.

${ }^{6}$ In one of the first studies of migration as insurance, Rosenzweig and Stark (1989) structurally model how marriage migration in rural India (which is another kind of permanent migration linking families across space) implicitly insures households against agricultural income risk and find evidence for their model in the six ICRISAT villages. Taking a different angle on migration, Jayachandran (2006) shows that limited access to outside labor markets exaggerates negative wage effects of local productivity shocks by swelling the ranks of local labor supply. Morten (2013) addresses how different types of coping strategies like temporary labor migration and informal insurance interact in rural India. Yang (2011) provides an overview on the remittance literature in economics.
} 
The main results have implications for policy. While apartheid-era restrictions on labor migration represent one example of spatial segregation, similar legal restrictions have controlled internal migration in China, Israel, Malaysia, Russia, and the Ukraine in the past. Most countries restrict travel and employment for foreigners using external passport and visa controls. In other settings, the nature of the physical terrain or inadequate transport infrastructure spatially segregates labor markets. The empirical evidence in this paper suggests we can expect local environmental shocks to have larger, long-lasting effects on health human capital in parts of the world where geographic, legal or political barriers constrain migration. ${ }^{7}$

The paper begins by setting out the historical background on labor mobility restrictions in TBVC and non-TBVC homelands in South Africa and provides initial empirical evidence on how these areas are alike, and how they differ in access to migrant networks during apartheid. Section 2 describes the research design, Section 3 the data and key variables and Section 4 the main results for disability, cohort size and fertility. Section 5 interprets these results in light of the differences in migration restrictions across homelands and provides additional evidence on how these restrictions may have contributed to the long run health impacts. It also discusses other potential explanations for the results. Section 6 concludes.

\section{Mobility restrictions in South Africa during apartheid}

Throughout formal apartheid (1948-1994), Africans were never entirely free to move around the country for work or other reasons. ${ }^{8}$ The white government implemented highly organized system of documentation and control to allocate African labor to firms, farms and households. For example, Africans were legally required to carry pass books with up-to-date work and travel permissions and to produce them on demand or face imprisonment. Rather than searching freely for work, job seekers had to register at local labor bureaux for work permits.

\footnotetext{
${ }^{7}$ The long-term health gains from reducing barriers to migration in such contexts would form part of the welfare gains from migration discussed in Clemens (2011) and modeled in Desmet and Rossi-Hansberg (2012).

${ }^{8}$ Wolpe (1988), Simkins (1983), Lemon (1984), Savage (1986) and Maylam (1990) discuss the main policies of population control under apartheid. Lemon (1984) writes "Probably no avowedly capitalist country controls its labor market to the same degree as South Africa....State restrictions on freedom of movement continue to hinder Africans in particular from selling their labor freely."
} 
A crucial component of the strategy to control African mobility to the urban areas involved the creation of ten homeland "states" or Bantustans during the 1950s, 1960s and 1970s. These homeland areas were established largely on pre-existing Native Reserve areas and confined excess labor and non-labor resources (women, children and the aged) far from urban centers, in rural parts of the country where land quality was generally poor. ${ }^{9}$ Several million Africans were resettled in these homelands by the 1960s (Simkins, 1983). My empirical analysis focuses on how residents of these different homelands were differentially able to respond to local drought.

The four earliest homelands - the Transkei, Boputhatswana, Venda and Ciskei, or TBVC areas were formalized in prior Native Reserve areas between 1959 and 1962. The remaining nonTBVC homelands - QwaQwa, KwaZulu, Gazankulu, Lebowa, Kangwane and KwaNdebele were established much later in the period, between 1969 and $1977 .{ }^{10}$ Reasons for this staggered formalization were primarily political. To ensure continued control of homeland administrations, the apartheid government needed time to establish appropriate bureaucratic structures in these rural areas and ensure that local chiefs would be sufficiently compliant (Evans 1997).

Once assigned to an established homeland, a person had extremely limited rights to live and look for work outside of this area. He was prohibited from migrating freely between homelands, as well as between homelands and urban areas. Children could not move at all, and requests for labor migration permits for adults (first men, and then women too) were made through labor bureaux located within the assigned district (Greenberg and Giliomee 1983). These offices registered jobseekers, posted job requisitions from South African companies, and certified job contracts. Signing up at the local labor office was a necessary step for all migrant workers,

\footnotetext{
${ }^{9}$ Native Reserve Areas were demarcated as early as 1913 and expanded in 1936. Evans (1997) describes how fear of massive demographic shifts in white urban areas was the primary motivation for the establishment of these reserves to house the majority black population.

${ }^{10}$ Transkei, Boputhatswana, Venda and the Ciskei were established in 1959, 1961, 1962 and 1961 respectively and legally granted independent status in (order) October 1976, December 1977, September 1979 and 1981. The remaining homelands were established: QwaQwa (1969), KwaZulu (1970), Lebowa and Gazankulu (1971), KaNgwane (1976) and KwaNdebele (1977).
} 
making these labor offices the official gatekeepers for legal African labor migration out of the homelands. ${ }^{11}$

The apartheid bureaucracy that authorized legal migration also restricted what the state viewed as illegal, or uncontrolled, migration. Between 1916 and 1984, nearly 18 million "Pass Law" arrests were made for illegal movement (Maylam 1990). Although legal mobility restrictions could not prevent all unauthorized African movement (Reed 2012), these restrictions substantially raised the costs of free internal migration for Africans living in homelands.

During the time that legal migration restrictions were in force, between 1948 and1986, the costs of migration were highest for residents of a subset of the homeland areas: the TBVC states. These were the earliest established homelands, and hence the first areas to be subject to all of the apartheid bureaucracy supporting the population migration policies. The TBVC areas were also the only homelands to gain political independence from South Africa in the late 1970s (Savage 1986). This meant that everyone in these four homelands required a formal passport to enter South Africa. The basic empirical strategy for the heterogeneity analysis compares outcomes for cohorts from these early versus late homelands, born in drought and non-drought periods.

Figure 1 shows the ten homelands scattered across the country. I use maps like Figure 1 and ArcGIS software to spatially identify which modern district boundaries cover a "majority homeland or TBVC area" and assign each district $d$ a value of $T B V C_{d}=1$ or 0 based on this spatial match. The Data Appendix describes this assignment in more detail. Note that the homelands are spread out across the country, and so capture a range of different climate conditions and variation in drought events.

Legal barriers to spatial mobility could contribute to how drought affects long-run health outcomes of drought across TBVC and non-TBVC areas in two ways. First, contemporaneous migration in response to a drought was more feasible from non-TBVC areas where migration

\footnotetext{
${ }^{11}$ In Secretary for Bantu Administration and Development General Circular No. 25 (1967), “1. It is accepted Government policy that the Bantu are only temporarily resident in the European areas of the Republic, for as long as they offer their labour there. As soon as they become, for some reason or other, no longer fit for work or superfluous in the labour market, they are expected to return to their country of origin or the territory of the national unit where they fit in ethnically if they were not born and bred in the homeland.”
} 
costs were lower, meaning that families could send out new migrants and access new remittances more easily during a drought. Second, and more importantly, differences in access to migrant networks - the cumulative result of differences in mobility restrictions across the entire period likely enabled families to tap remittance flows to mitigate the negative effects of drought. Historical accounts of the South African economy suggest that these cumulative migrant networks were an important part of how families coped with local environmental shocks, as Nattrass and Seekings (2011) illustrate:

"the consequences of natural disasters were mitigated by the integration of rural societies into a cash economy through labo(u)r (sic) migration.... the factors that propelled as many as one in three adult men of working age to migrate routinely to the mines or other employment served to ensure that a cash income flowed into rural areas even when drought or pestilence reduced production".

In Section 3, I present descriptive statistics highlighting differences in access to migrant networks observed across TBVC and non-TBVC areas as a result of differences in the externally-imposed migration limitations. I also show that access to migrant networks looks more similar across these homelands after 1986, when legal restrictions on mobility were repealed and the homelands were reincorporated into South Africa.

\section{Empirical strategy}

To begin, I identify the main effect of early life drought exposure on long-term health outcomes for all homeland residents using a difference-in-differences research design. I use multiple drought events to compare health outcomes across drought and non-drought cohorts, controlling for average differences in these health outcomes across years and across districts. Census data provide two important categories of health measurement: self-reported disability and cohort size.

Using individual-level observations on disability and drought exposure and controlling for birth district $\mu_{d}$ and birth year $\phi_{t}$ fixed effects, I estimate the following regression for disability outcomes $Y$ of person $j$ born in district $d$ in year $t$ :

$$
Y_{j d t}=\beta_{0}+\beta_{1} \text { DROUGHT } T_{d t}+\mu_{d}+\phi_{t}+\omega_{j d t}
$$

where DROUGHT $T_{d t}$ is a measure of drought exposure in early life. I estimate this specification using the full sample as well as separately for men and women, following prior research that 
documents the particular sensitivity of males to early-life nutritional insults (Almond and Mazumdar 2011, Almond 2006; Almond and Currie 2011a). Robust standard errors are clustered on year of birth to adjust for within-year spatial correlations between health outcomes and drought (Bertrand, Duflo and Mullainathan 2004). ${ }^{12}$

Since the Census only asks current and previous district of residence, I define birth district as a person's prior district of residence for someone who has ever moved, and current district of residence for someone who has never moved. This means that for some fraction of individuals people who have moved more than once, for whom district of prior residence is not district of birth - drought exposure in early life is mis-measured, leading to downwards bias in estimates of $\beta_{1}$ (Bound, Brown and Mathiowetz 2001).

As an additional population health outcome, I measure the impact of drought exposure on log cohort size at the district level $\left(Y_{d t}\right)$ and estimate district-year level regressions with the same set of controls as in (1). Since drought may be severe enough to affect total population through adjustments in total mortality and total fertility (Almond and Mazumdar 2011, Martorell 1994), I investigate fertility impacts by estimating the effects of drought exposure during childbearing years spent in TBVC and non-TBVC areas on total completed fertility of women aged 40 to 60 in 1996.

The main effect of drought exposure in early life in all homelands is captured by $\beta_{1}$. Withindistrict variation in birth timing relative to drought identifies this coefficient. Birth year fixed effects in equation (1) account for age effects in health outcomes and for contemporaneous national shocks affecting these outcomes. District fixed effects control for constant unobservable differences between districts that may affect health, for example: some districts may be droughtprone, have different access to public health facilities, or different approaches to child health investments.

\footnotetext{
${ }^{12}$ Drought conditions within a district are uncorrelated over time. After controlling for year and district fixed effects there is no first order serial correlation in errors for the drought indicator. The coefficient from the lagged residual regressions for drought is .025 ( $p$ value $=.36)$.
} 
The key identification assumption for this difference in differences design is that there are no contemporaneous shocks to health in drought years. This assumption rules out (for example) changes in national government assistance affecting all homelands in a drought year. An attractive feature of my research design is that because there are multiple drought events in different districts across many different years, I exploit many separate natural experiments to identify the effects of drought rather than relying on a single drought event. So, for example, fluctuations in government policy towards the homelands (e.g. Pass Laws were more heavily enforced in later years of the analysis period) are highly unlikely to be correlated with each and every drought event in the data.

To investigate heterogeneity in the long-run health effects of drought, I leverage a third source of variation and compare the long-run health effects of drought exposure across two subsets of homelands, the TBVC and the non-TBVC areas, while controlling for district and year fixed effects. I modify (1) to estimate the following regression:

$$
Y_{j d t}=\delta_{0}+\delta_{1} D R O U G H T_{d t}+\delta_{2} D R O U G H T_{d t} * T B V C_{d}+\mu_{d}+\phi_{t}+\omega_{j d t}
$$

where $T B V C_{d}$ indicates whether the birth district falls within the boundaries of a TBVC state or not, and all other variables are measured as before. ${ }^{13}$ The main parameter of interest in this regression is $\delta_{2}$, the differential effect of drought in early childhood in TBVC relative to nonTBVC areas. As before, within-district variation in birth timing relative to drought events identifies $\delta_{1}$ and $\delta_{2}$. If drought negatively affects health in both areas, disability rates will be higher for cohorts with greater early-life drought exposure ( $\delta_{1}>0$ and $\delta_{2} \geq 0$ ) and cohort size will be smaller ( $\delta_{1}<0$ and $\delta_{2} \leq 0$ ). If families in TBVC areas are less able to respond to drought, then $\delta_{2}$ will be strictly greater than zero for disability outcomes and strictly less than zero for cohort size outcomes.

Motivated by the historical context in Section 1, this paper argues that differential access to migrant networks, created by differences in externally-imposed migration restrictions,

\footnotetext{
${ }^{13}$ One interpretation of this approach is as a triple difference regression, although perhaps a more natural way to think about this regression is as a difference-in-differences regression that also controls for year of birth and district fixed effects.
} 
contributes to the size and sign of $\delta_{2}$. Descriptive statistics in Section 3 illustrate this differential access to migrant networks before 1986. However, there could be other differences between TBVC and non-TBVC areas that are not differenced out by the district fixed effects in equation (2), and which influence how well households in TBVC and non-TBVC areas cope with drought. For example, differences between TBVC and non-TBVC districts in mean levels of access to credit or savings facilities, access to public health and other social services, access to jobs and markets, and agricultural potential may enable households to differentially cope with drought, thereby confounding the interpretation of $\delta_{2}$.

I pursue three strategies to account for many of these other differences between areas. First, I estimate equation (2) controlling for drought interacted with district-level population density in 1946 (a proxy for access to social services, credit and jobs), agricultural potential of the land (specifically, an index of suitability for maize production), and a measure of geographic remoteness (also a proxy for access to social services, credit markets and jobs). If results are robust to these controls of baseline district characteristics, we can be more confident that such fundamental differences between TBVC and non-TBVC districts do not explain differences in the long-term health effects of drought exposure.

Second, I use the Census data to implement a placebo test. Using the same regression specification as in equation (2), I estimate effects of drought on children born in ex-homelands since the repeal of mobility regulations. That is, the sample includes children born between 1987 and 1993 in districts that were formerly part of TBVC and non-TBVC areas. This allows me to check whether differential health effects of drought across TBVC and non-TBVC areas are evident even after legal limits on migration are repealed. If the spatial mobility channel is an important factor contributing to $\delta_{2}$, they should not be.

Finally, I present direct evidence on how access to migrant networks affects the ability of families to mitigate the impacts of drought. I cannot show that remittances respond to drought contemporaneously for the 1948 to 1986 period since there are no spatially disaggregated data on remittance flows during apartheid. Instead, to provide evidence of mechanism, I estimate how remittances respond to unexpected drought using data from more recent years and the following regression: 


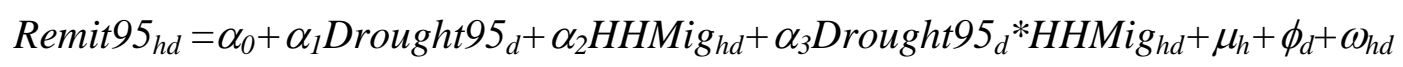

where Remit95 ${ }_{h d}$ is an indicator for whether household $h$ in district $d$ received any remittance in 1995. This regression asks whether remittances respond to drought even in current periods, and whether these flows are facilitated through existing migrant networks (pre-existing household migrants). To this end, the regression controls for differences in average remittance receipts between households in districts that did not experience drought in $1995\left(\alpha_{1}\right)$, for differences in average remittance receipts across households with any migrant worker versus no migrant worker $\left(\alpha_{2}\right)$, and for historical drought prevalence to soak up any district-level unobservables affecting average remittance receipts $\left(\phi_{d}\right)$.

Under the assumption that historical drought prevalence adequately controls for unobservable differences between districts that affect mean remittances, I treat drought in 1995 as uncorrelated with remaining unobservable factors, that is, conditional on controls, any drought in the year before the survey was a surprise. I estimate (3) for all households in the former homeland areas and separately within TBVC and non-TBVC areas and show that in both areas, remittances are the key link between adult outmigration and sending households. Remittances increase resources for those left behind during drought, but only in those households connected to a migrant network.

\section{Data and key variables}

\section{i. $\quad$ Measuring drought}

I use rainfall data from over 1,000 local weather station locations to construct a district-year specific drought measure using the Standardized Precipitation Index (SPI) (McKee, Doesken and Kleist 1993). ${ }^{14}$ The SPI measures the probability of observing a recent rainfall event based on the distribution of all rainfall events for a given time scale and place, and characterizes South African droughts well (Roualt and Richard 2003). Following the climatological literature, I

\footnotetext{
14 There is no consensus on how the onset, duration or completion of a drought should be marked (Wilhite, 2001; World Meteorological Organization 2006), however, the climatological literature has shown the robustness of the SPI in capturing precipitation deficiencies that extend over time (Roualt and Richard 2003).
} 
define DROUGHT $T_{d t}$ in each district $d$ and year $t$ to be 1 for values of the SPI below -1.5 and 0 otherwise (McKee et al 1993). The spatial specificity of this measure is important because the same quantitative rainfall deficit may indicate inadequate precipitation in historically wetter districts but not in historically drier districts.

Drought events are important for agricultural output in South Africa. The country's staple crop (maize) is rain-fed and limited water availability reduces maize output by interrupting growth at several points in the growing season (Le Roux 2009). Insufficient rainfall over an extended period has particularly negative consequences for yields. Data Appendix 1 shows that maize yields appear more sensitive to rainfall deficiencies than to rainfall excesses. Drought is therefore the relevant measure of an important local environmental shock in South Africa.

Figure 2 shows the distribution of these droughts during apartheid. This is the main source of variation used to identify the long-term effects on disability rates and cohort size in all homelands, and across TBVC and non-TBVC areas. Each bar represents the fraction of TBVC and non-TBVC districts experiencing a local drought in a given year. The figure shows substantial variation over time: some years are entirely drought-free (e.g. 1975) while in other years (the early 1980s) over 30\% of districts experience drought. In most years, a smaller, positive fraction of districts experience drought.

I measure drought exposure (DROUGHT $T_{d t}$ ) in two ways, both of which vary at the birth district and birth year level. The simplest measure is an indicator for whether district $d$ experienced a drought in year $t$ (the year of birth of the individual) or not. The second measure captures the fraction of years from in utero to four years of age that a person was exposed to drought in their birth district. ${ }^{15}$ By exploiting the fact that some individuals were exposed to multiple drought

\footnotetext{
${ }^{15}$ Although the economics literature has recently provided much evidence for the fetal origins of disease, or, the long-term health effects of nutritional deprivation and exposure to environmental toxins in utero (see Almond and Mazumdar (2011) for a discussion of biological mechanisms in utero), infants and children continue to be vulnerable to malnutrition and infection after birth, with potential long-run consequences. Martorell (1999) indicates that until 3 years of age, the physical and mental development of a child remains in the critical period because growth rates are higher during this time than in any other period of life and because infant immunological systems are still developing. For example, the critical period for the development of binocular vision is between 3 and 8 months, while neuronal development of the vestibular system (which affects motor skill development) has a critical period in the first three weeks of life (Rice 2000). Even mild malnutrition and associated micronutrient deficiencies
} 
events in early childhood, depending on their year of birth and place of birth, this second measure captures the intensity of drought exposure at a range of critical ages when nutritional deficiencies can affect later health outcomes. ${ }^{16}$

\section{ii. $\quad$ Measuring disability and population composition using Census data}

I use the 10\% individual record data from the 1996 South African Census to construct the sample for the disability and cohort size analysis. I also use these data to investigate the fertility response to drought exposure. The main sample consists of African individuals born between 1948 and 1986 (age 10-48) whose current district (for never movers) or prior district (for movers) is in a rural TBVC or non-TBVC homeland. ${ }^{17}$ Individuals report whether they have any serious disability and the type of disability: vision, hearing or speech, mental or physical disability (e.g. paralysis). I construct an indicator for “Any serious disability?” and a "Number of serious disabilities" variable for the main analysis. ${ }^{18}$

(vitamin A, folic acid, zinc, iodine, and iron) during this period can contribute to a syndrome of "developmental impairment” that includes growth failure (stunting and wasting), delays in cognitive, motor and behavioural development, lower levels of resistance to disease, and increased morbidity and mortality (Martorell 1999). In the well-known INCAP study in Guatemala, a randomized nutritional intervention for pregnant women and infants led to taller, heavier adults with greater strength and work capacity, and higher wages (Martorell 1999, Hoddinott et al 2008). Schroeder et al (1995) show that nutritional intervention before three years of age had the largest impacts on health outcomes for children. Case and Paxson (2010) use data from numerous surveys to show that height deficiencies in childhood (an outcome of nutritional deprivation) are strongly correlated with significantly higher rates of disabilities and poorer health in later life.

${ }^{16}$ The Census asked for month of birth information but these variables are not reported in the public data. Annual drought exposure is a reasonable measure of early life exposure since precipitation deficits measured over a longer period of time more accurately reflect conditions of drought than acute rainfall shocks over shorter periods. To interpret the fractional measure of drought exposure, it is important to note that permits were never granted for children to move outside of homelands with any parent. Hence, district at birth is likely to be the same district throughout early childhood for this sample. An alternative way of capturing drought exposure in early childhood would be to include multiple indicators for drought in each year of life (rather than the fractional measure). Estimates of health results using this specification are broadly similar, but point estimates on each year of exposure variable are noisy, likely because the year of birth data are noisy. Since this paper focuses on how families cope with drought rather than on identifying the exact timing of when drought exposure in infancy matters the most, I do not present estimates from these alternate specifications.

${ }^{17}$ Sample selection is discussed in detail in the Data Appendix.

${ }^{18}$ Self-reported disability variables capture meaningful variation in health status across individuals. For a similarly aged sample in the South African National Income Dynamics Study (2008), each additional self-reported disability raises a person's score on an index of difficulties with activities of daily living (ADLs) by 0.75 of a standard deviation. This highly significant correlation is conditional on age, gender and age-gender interactions. 
Table 1 shows that TBVC and non-TBVC areas are similar on a range of observable characteristics: the adult sample is balanced on age (23 years), education, and individual-level exposure to drought in birth year and throughout early childhood. Differences in the fraction of women in TBVC and non-TBVC areas are significant at the 5\% level, but small.

TBVC areas are more remote than non-TBVC areas, and less suited to maize production than non-TBVC areas, although these differences are not statistically significant. They have lower population density than non-TBVC areas (also not significant). These three variables are the main district-level controls used in the robustness check regressions.

Table 1 Panel A shows disability prevalence in the sample. 5.2\% of individuals report a serious disability, with vision being the most prevalent disability (2.3\%). 1.1\% of the sample has a hearing/speech disability and $1.4 \%$ have a physical disability; mental disability is reported at much lower rates $(0.7 \%) .{ }^{19}$ These disability rates do not merely reflect diseases of old age since the sample includes people aged 10 to 48 .

Differences in mean disability rates across TBVC and non-TBVC areas in Table 1 foreshadow the main health results. For all outcomes, disability rates are higher, sometimes substantially so, for the TBVC sample than for the non-TBVC sample. Constant differences in disability rates across areas are controlled for by district fixed effects. The regression specification in (2) seeks to estimate the differential differences in disability rates in drought versus non-drought periods.

The table also presents information on total fertility rates for women in TBVC and non-TBVC areas. Among cohorts of women who have completed childbearing by 1996 (aged 40 to 60), total fertility rates are about 4.7 children per woman. Women from TBVC areas have significantly higher total fertility rates than women in non-TBVC areas. For each woman in the fertility sample, I compute the fraction of her childbearing years (1951-1996) exposed to drought. ${ }^{20}$ Table 1 Panel A shows that drought exposure in this sample of women is slightly higher in TBVC than non-TBVC areas. This suggests that endogenous fertility responses may contribute to some of the health effects, and I investigate this channel after presenting cohort size results.

\footnotetext{
${ }^{19}$ These rates are comparable with disability rates for Uganda reported in Almond and Mazumdar (2011).

${ }^{20}$ I use the prior district designation as the relevant location for each woman's drought exposure.
} 


\section{iii. Measuring differences in migrant networks across TBVC and non-TBVC homelands}

The distinction between TBVC and non-TBVC homelands captures meaningful variation in spatial mobility and differential access to migrant networks between 1948 and 1986. Figure 3 shows the percent of adults living in a given district in a given year that permanently migrate away from that district, by TBVC and non-TBVC homelands (Variables are constructed from last-move data in the 1996 Census, details in the Data Appendix). ${ }^{21}$ Maximum annual outmigration is low in level terms. Only $0.6 \%$ of the district-level adult population migrates away in later years. Importantly, Figure 3 shows that permanent outmigration from non-TBVC areas is higher than outmigration from TBVC areas in almost all years; consistent with the idea that spatial mobility was more restricted in TBVC districts under apartheid.

It is important to note that in the South African context, permanent migration does not imply that a migrant worker has no further attachment to a household. It is common for permanent migrants to continue to be associated with their rural homes and be listed on the household roster as absent household members for long periods of time (Posel, 2011), even if they do not intend to permanently return to those households. Differences in annual permanent outmigration rates therefore contribute to differences in access to migrant networks across TBVC and non-TBVC areas.

Table 2 presents summary statistics for a larger range of migration indicators by TBVC area. The average annual district outmigration rate between 1948 and 1986 is 0.2\% in TBVC areas, and $0.3 \%$ in non-TBVC areas. These annual rates are low, but they cumulate to larger differences in access to migrant networks over this period. By 1986 the share of adults who have migrated away from non-TBVC areas is a statistically significant 2.1 percentage points higher in nonTBVC areas relative to TBVC areas. ${ }^{22}$

\footnotetext{
${ }^{21}$ There are no Census data on circular, seasonal or temporary migration. Such migration may also play an important role in helping families cope with local income risk, as in Bryan, Chowdhury and Mobarak (2012). If permanent migration rates are correlated with more temporary migration, this will be captured as part of our reduced-form estimates for health.

${ }^{22}$ Simple simulations in Appendix Table 1 shows how small differences in the annual probability of outmigration cumulate to larger differences in the fraction of adults who have ever migrated and the fraction of households with a migrant.
} 
Some of these differences disappear in the years after mobility restrictions are repealed and before the transition to democracy (1987-1993). The cumulative share of adults that outmigrates between 1987 and 1993 rises to 14\% in both TBVC and non-TBVC areas and the difference is no longer statistically significant. However, the legacy of differential access to migrant networks is reflected in continued large differences in the fraction of households receiving any remittances in 1993, the closest year to 1986 in which there are data on remittance receipts for a nationally representative sample. ${ }^{23} 39 \%$ of TBVC households receive remittances in 1993 while $49 \%$ of households in non-TBVC homelands do.

The statistics in Table 2 also indicate the central role of remittances in supporting households in all ex-homeland areas in 1993. Not only are remittances prevalent, but remittance contributions to household income are quantitatively large. Mean monthly remittance income in households listing a migrant worker on the roster are just over ZAR200, or around \$65 per month. This accounts for just over one quarter of monthly household income. ${ }^{24}$

These summary statistics support the idea that differences in externally imposed mobility restrictions across the two types of homelands resulted in real differences in access to migrant networks.

\section{Main Results}

\section{i. Main effects of early childhood drought exposure on disability and cohort size}

Table 3 presents the main effects from estimating the regression in equation (1). For each of the outcomes “Any serious disability”, “Number of serious disabilities” and "Log cohort size”, I present results for the two measures of drought exposure using the full sample in columns (1) and (2) and results for male and female samples separately in columns (3) through (6).

\footnotetext{
${ }^{23}$ See Casale and Posel (2006) for more on the link between permanent outmigration and remittance flows across households in South Africa.

${ }^{24}$ De Beer (1984: 57) describes migrants as "the most privileged people in the reserves". He estimated that an average worker from the Ciskei, working illegally in a large city for three quarters of the year and spending the remaining months in jail for pass law violations would still increase their standard of living by $700 \%$.
} 
Coefficients on variables for fraction of early childhood in drought are evaluated at the mean fraction of early life exposed to drought.

Greater exposure to drought in early childhood significantly raises the chance of having a serious disability. For a mean level of drought exposure, disability rates are 0.1 percentage points higher (Panel A), and the average number of disabilities is about 2.1\% higher (Panel B, not significant). Cohort size is about $0.7 \%$ lower (Panel C, not significant). Splitting the sample by gender, we see that while drought in early life negatively affects health of both men and women, the size of these negative effects is uniformly larger for the male sample. These negative effects of drought are also much more precisely estimated for men than for women. At the mean level of drought exposure, the male disability rate is 0.2 percentage points higher ( $4.7 \%$ relative to mean rates), males have $4.3 \%$ more disabilities and male cohort size is $1.1 \%$ smaller.

\section{ii. Heterogeneous effects of early childhood drought exposure on disability}

The next set of results focuses on estimating the heterogeneous effects of drought exposure in early life on disability outcomes by TBVC and non-TBVC status of the birth district. Table 4 presents results from estimating equation (2) first for the pooled sample and then separately for males and females. Using the fraction of the period from in utero to age 4 as the main drought exposure measure, we see that mean levels of exposure raise disability rates across the board in non-TBVC areas. Effect size ranges from 0.1 to 0.2 percentage points for disability prevalence, and these are fairly precise estimates. The results using drought in the birth year as our exposure measure point in a similar direction in the non-TBVC areas, although effects are less precisely estimated. This is likely because exact year of birth information, as well as district of birth information, are measured with some error.

Table 4 shows clearly that the effect of drought exposure in early life is significantly larger for individuals born into TBVC areas. At the mean drought exposure rate, TBVC individuals in the pooled sample are twice as likely to have a serious disability as non-TBVC cohorts and have 1.7\% more disabilities than non-TBVC cohorts, relative to the mean number of disabilities. Adding the main and interaction effects together, we see that mean drought exposure in early childhood raises disability rates among TBVC cohorts by $4 \%$. 
Results using drought exposure in birth year (columns (2) and (4)) are similar. Drought exposure at birth raises disability rates in both TBVC and non-TBVC areas, with the negative health impacts being three times larger in the TBVC areas. Although neither main nor interaction effects are precisely estimated in these two columns, drought parameters are jointly significant at the 5 and 10\% level respectively. Moreover, in this pooled sample, the effect of drought on disability rates in TBVC areas (the sum of $\delta_{1}$ and $\delta_{2}$ ) is significantly different from zero at the $5 \%$ level.

Columns (5) through (12) show that the male sample drives these differences in the disability effects of drought across TBVC and non-TBVC areas. Mean drought exposure in early childhood raises male disability rates by about 0.2 percentage points and the number of serious male disabilities by 0.002 (3.5\%). In TBVC areas, drought exposure effectively doubles these effect sizes. Using mean drought exposure before age 5, males born in TBVC areas are 0.2 percentage points more likely to have a disability. Using the drought in birth year indicator, males born into TBVC areas report 0.9 percentage points higher disability rates. These male results are precisely estimated and represent economically meaningful magnitudes. Relative to the average level of disability in the male sample, drought in the birth year in a TBVC area raises male disability rates by almost 20\%, while mean drought exposure over the first four years of life raises disability rates by about $4 \% .{ }^{25}$ I reject the hypothesis that mean drought exposure has no effect on the chances of disability and the number of disabilities for males later in life at the $1 \%$ level ( $p$-values of the joint tests are 0.009 and 0.008 respectively). ${ }^{26}$

In contrast, mean drought exposure in childhood and drought in the birth year has no differential impacts on disability rates among females from TBVC relative to non-TBVC areas. While drought exposure raises disability rates among females in all areas (the main effect), I cannot reject the joint hypotheses that drought in the birth year has no differential impact on female

\footnotetext{
${ }^{25}$ The differences in these numbers arises because the fraction of early childhood in drought measure averages over all individuals who may be exposed to drought in any of their first 4 years of life and during the in utero period. ${ }^{26}$ Appendix Table 2 explores which components of male disability are most sensitive to drought exposure around birth. Results indicate that drought exposure around birth and mean drought exposure in early childhood raises prevalence of all types of disabilities by more in TBVC areas. Heterogeneous effects are strongest for vision and physical disabilities, and are robust to controlling for baseline district controls interacted with drought measures.
} 
disability rates in TBVC areas ( $p$-value of the joint null is 0.16 and 0.22 for any disability and number of disabilities respectively). And, although the mean drought exposure variables are jointly significantly different in the female regressions of columns (9) and (11), the point estimates are far smaller than in the male regressions, and almost zero on the TBVC interaction terms. These sex differences in the disability effects of drought are consistent with theories that male infants are more fragile than female infants (Barker, 1995; Kraemer 2000).

Both because the literature had shown evidence that male babies are more susceptible to negative effects of early life health shocks (e.g. see Almond and Mazumdar 2011) and for more practical purposes - the male sample estimates are larger and much more precisely estimated than for females, providing more power for testing mechanisms - I restrict the remainder of the disability analysis to the male sample.

Table 5 provides robustness checks for these male health impacts. Columns (1), (2), (5) and (6) reproduce the male results from Table 4. The remaining columns present results for the same outcomes from regressions that control for interactions of baseline district-level variables (population density in 1946, remoteness and agricultural potential) with drought measures.

Almost all the coefficients on drought variables increase in size after controlling for these district-level variables and are more precisely estimated. Rather than explaining the differential effects of drought in TBVC areas, adding in these district variables amplifies the impact of drought in TBVC areas and absorbs residual variation in the outcomes. Estimates of $\delta_{1}$ and $\delta_{2}$ are not apparently driven by district-level differences in remoteness, population density or agricultural suitability across TBVC and non-TBVC areas that could condition the effect of drought on health outcomes differentially by area.

\section{iii. Heterogeneous effects of early childhood drought exposure on cohort size and fertility}

Table 6 presents results for cohort size regressions. Cohorts exposed to the mean rate of drought up to age 4 are smaller in all areas but this difference is not significant. In TBVC areas, drought cohorts are significantly smaller - on the order of 2 percentage points. Results are similar, although much more noisily estimated, using drought exposure in the cohort's birth year. The TBVC interaction terms are about $60 \%$ larger for the male sample, relative to the female sample. 
This larger effect of drought on male cohort size indicates that drought exposure may differentially raise male infant mortality or reduce the number of male fetuses conceived.

To assess whether drought directly affects total fertility (there are no historical data on infant mortality rates), I estimate regressions for total completed fertility among women ages 40 to 60 in TBVC and non-TBVC areas. I assume each woman bears her children in the same district reported as her first district. ${ }^{27}$ I regress total completed fertility on the fraction of a woman's childbearing years (ages 15-40) during which she experienced drought and the interaction of this exposure measure with the TBVC status of the district, controlling for first district fixed effects and birth year to capture mother age effects.

Table 7 presents results for the full sample of women (column (1)) and for subsamples of women with different levels of education. Total fertility rates are significantly lower ( 0.22 fewer births, or about $4.7 \%$ relative to the mean) when women are exposed to the mean years of drought during their childbearing years. This effect is driven by women in TBVC areas and in particular, by mothers without education. This negative effect of drought exposure on total fertility is consistent with negative cohort size effects in drought years in TBVC areas (Table 6).

Results in Tables 6 and 7 have three implications. First, the long-run impact of drought on population is sizeably negative, and especially so in TBVC areas. One of the ways this appears to occur is through reduced fertility. Women exposed to more drought during their childbearing years have significantly fewer children. Second, because of this perhaps, the disability results may capture a "scarring" effect of exposure to drought in early childhood as in Bozzoli, Deaton and Quintana-Domeque (2009). Alternatively, if survivors are positively selected rather than scarred (as might be the case since mothers with less education cut back on fertility even more in TBVC areas) then the disability results for males in Tables 4 and 5 may underestimate the longrun health impacts of drought in TBVC areas.

\section{Mechanisms: Interpreting larger negative impacts of drought among TBVC cohorts}

\footnotetext{
${ }^{27}$ This assumption generates a noisy assignment of first district for the (likely small) fraction of women who moved multiple times during apartheid.
} 
Consistent with prior evidence on the impact of childhood exposure to shocks on later life health, the results of the analysis in Tables 3 through 6 show that early-life drought exposure has significant negative impacts on the prevalence of disabilities and on cohort size of Africans from former homeland areas, with larger and more precise estimates in the sample of males. Drought exposure accounts for an even higher fraction of total disability for African males born into TBVC areas.

Section 1 argued that a key difference between TBVC and non-TBVC rural homelands was the intensity of external mobility restrictions facing each group. Figure 3 and Table 2 showed that TBVC areas had lower outmigration rates than non-TBVC areas during 1948-1986, and that lower levels of remittance receipts across these areas persist until as late as 1993. In this section, I provide additional evidence that differences in migration restrictions contributed to these differences in disability and population effects of drought across TBVC and non-TBVC areas. I also explore the mechanism through which migration matters, by estimating the responsiveness of migrant remittances to drought in more recent data. Finally, I discuss other possible explanations for the heterogeneous long-run effects of drought on health outcomes

\section{i. $\quad$ Testing migrant networks as a key channel: Placebo regressions}

If migration restrictions are an important part of the explanation for differences in disability effects of drought across TBVC and non-TBVC areas, these health effects of drought exposure in early life should attenuate for among cohorts born since the lifting of these restrictions. Legal restrictions on migration - most notoriously, the Group Areas Act - fell away in 1986, at which time all homelands were also reintegrated into South Africa. Table 8 presents estimates from a set of placebo regressions of equation (2) for the sample of males born between 1987 and 1993 (the last year of formal apartheid). ${ }^{28}$

For this sample of individuals aged 3 to 10 living in former homelands in 1996, we see that on average, drought exposure in early life still has negative consequences. Mean exposure to drought in early life raises disability rates by 1 percentage point, with drought in the birth year

\footnotetext{
${ }^{28}$ Summary statistics for this sample are in Appendix Table 3.
} 
raising disability rates by 1.8 percentage points. If anything, the negative effects of drought exposure are even worse after the homelands are reintegrated into South Africa (although it is important to remember that we are measuring the short-run and medium-run effects of drought on this younger sample; the magnitude of these effects is not strictly comparable with the older sample).

Notably, differential effects of drought across TBVC and non-TBVC areas are no longer observable in this younger sample. Disability rates are not differentially higher in TBVC areas than in non-TBVC areas, and if anything, they look slightly lower, although not significantly so in most cases. Results for the cohort size regressions are similar, and there no longer seems to be a negative effect of drought exposure in early life on cohort size for post-1986 cohorts. Table 8 results suggest that drought cohorts are larger in approximately the same way across TBVC and non-TBVC areas since the repeal of mobility restrictions. If the TBVC designation of homelands was really picking up other differences across areas that explain why drought has heterogeneous impacts across space, we should have expected the results of Table 8 to be similar to those in Tables 4, 5 and 6 . The fact that we do not gives more weight to the interpretation that migration and spatial mobility contributed to the heterogeneous effects of drought for cohorts born before 1986.

\section{ii. Testing migrant networks as a key channel: Do remittances respond to drought?}

Remittances are a key variable linking permanent outmigrants with health outcomes of family members who are left behind. Table 9 presents results from household-level regressions of remittance receipts (“Any remittances”) in 1995 on district-level drought in 1995, an indicator for whether a migrant worker is attached to the household, and the interaction of these two variables. Because households with and without migrant workers could differ on a number of unobservables it is important to control for the presence of a migrant worker attached to the household. I also control directly for the fraction of drought years experienced by each district between 1948 and 1995 to account for differences in average remittance behavior induced by the “drought-proneness" of an area. Columns (1) and (2) present results for the entire sample, while columns (3) to (6) break this out for former non-TBVC and TBVC districts. 
Even though this evidence on remittances comes from the post-apartheid period when legal barriers to labor migration are no longer in place, the legacy of historical mobility restrictions persists. In 1996, almost $40 \%$ of all households in rural TBVC districts and almost $50 \%$ of households in rural non-TBVC districts reported at least one migrant worker and one in five received some type of remittance the year before the Census. Conditional on having any migrant worker attached to the household, the chances of a household receiving any remittance were one in two.

The estimates in Table 9 show that drought exposure in 1995 has no significant impact on remittance receipts in households without a migrant worker. In contrast, migrant worker households in drought-exposed districts were a significant 2.7 percentage points more likely to receive any remittances in 1995 (column (1)) and this is robust to including baseline district controls interacted with historical drought prevalence. Drought raises the probability of receiving any remittances by $13 \%$ relative to the mean rate of remittances.

Splitting the sample into TBVC and non-TBVC areas, it is clear that having a migrant worker in the household facilitates remittances after drought in both areas. This relationship is somewhat more precisely estimate and a bit larger in non-TBVC areas, perhaps reflecting the stronger historical migrant links between these areas and the rest of the economy (although the sample size is also larger for the non-TBVC areas). For non-TBVC areas, drought exposure raises the chances of receiving remittances by over $16 \%$. The difference across TBVC and non-TBVC areas is not significant (results not shown), which makes sense since 1995 is almost 10 years after the repeal of the spatial mobility laws in homelands.

These remittance results show clearly how migrant networks are likely to matter for health outcomes of the left-behind in former homeland areas: migrants facilitate remittances overall, and remittance flows respond positively to local economic shocks. Differences in the probability of having access to such a migrant network generated by differences in apartheid restrictions on migration contributed to families being able to more effectively smooth income across space and cope with prevalent local environmental shocks.

\section{iii. Alternative interpretations of heterogeneous impacts of drought exposure}


This paper has argued that differences in spatial mobility restrictions, in access to migrant networks and the remittances these entail contribute to differential long-run health effects of drought across TBVC and non-TBVC areas. Empirical specifications controlling for district fixed effects and district baseline variables interacted with drought control for many other observable and unobservable differences between areas that condition the health effects of drought. However, there could be other reasons that explain why the disability and cohort size results are so much more negative in TBVC areas. Three important channels are worth considering.

First, crops may be more sensitive to drought conditions in TBVC areas. If this is the case, then drought implies a different intensity of shock to health human capital in each area, regardless of differences in mobility restrictions. The robustness of the main disability and cohort size results to controls for drought interacted with underlying agricultural potential of each district gives us some assurance that such differential physical responses to drought do not explain the health results. Appendix Table 4 shows directly that maize, grain, and general crop output yields are not differentially responsive to drought in the last year across TBVC and non-TBVC ex-homeland areas. $^{29}$

Perhaps the strongest argument against this channel is that subsistence agricultural production was negligible in all homeland areas (Dinkelman 2011; Nattrass and Seekings 2011). ${ }^{30}$ Data from the end of apartheid suggests that the value of agricultural production in rural areas contributed far less to household income than remittances and other sources of income from kin (Nattrass and Seekings 2011). Differential sensitivity of agricultural production to drought across TBVC and non-TBVC areas does not provide a ready explanation for the differential long-run health effects of drought exposure.

\footnotetext{
${ }^{29}$ Unfortunately, the data available for this exercise are very noisy. This is because there is a very low level of subsistence farming in these areas. Nonetheless, there is no strong evidence to support the case that crops grown in former TBVC homelands are more sensitive to drought conditions in 1992.

${ }^{30}$ Excluding commercial farming, agricultural production is estimated to have made up only $1 \%$ of total income in South Africa in 1993 (Nattrass and Seekings 2011).
} 
A second channel that may differentiate TBVC from non-TBVC areas in their ability to cope with drought (regardless of spatial mobility differences) is through differential access to private, formal insurance mechanisms, public insurance, social safety nets and social services. Showing that results were robust to including controls for drought interacted with baseline population density and district-level measures of remoteness was one way to address this concern quantitatively.

In fact, prior research documents very low access to private and public safety nets in the former homeland areas. Private savings and insurance mechanisms (e.g. banks) were virtually nonexistent in rural homelands during apartheid and public services for homelands were uniformly underprovided (Brown 1987). As some examples: over three quarters of Africans (across the entire country) were unbanked in 2001, with a much higher fraction of unbanked in rural areas; only $8 \%$ of households in the lowest income quintile had a bank account (Ardington et al 2011). ${ }^{31}$ Health services in the homelands absorbed only $0.23 \%$ of South African GDP by the mid-1970s, even though these areas housed 32\% of the population (Price 1986). ${ }^{32}$ Chronic underfunding of public health services undoubtedly contributed to high baseline levels of malnutrition in all homelands and a high prevalence of kwashiorkor and marasmus, respiratory infractions, gastroenteritis, and measles among children (De Beer 1984) which might have made homeland populations more susceptible to drought shocks overall. But there is no reason to expect that baseline health was worse in TBVC states than in non-TBVC states. If anything, TBVC states had marginally more per capita resources for health care than the non-TBVC states, since the government used spending promises to promote the adoption of political independence (De Beer 1984).

A third difference between the two areas that could explain differential disability responses to drought even in the absence of migration is differential access to informal insurance mechanisms. Households might be able to borrow or lend informally amongst themselves, or self-insure using buffer stocks or grain storage, or rely on resources from group savings and

\footnotetext{
${ }^{31}$ Ardington (1999) surveys financial facilities in one rural area of South Africa and finds whole districts without any banks or post offices in the mid-1990s.

32 The average doctor: patient ratio across homelands during this time was 1:15 000 (Coovadia et al 2009).
} 
insurance mechanisms. Although these informal insurance mechanisms certainly exist in South Africa, they are less useful when drought hits an entire district, which is the measure of drought used in this analysis. Furthermore, researchers have documented that in South Africa, access to formal and informal risk-sharing mechanisms is complementary: people who have bank accounts are also more likely to participate in (for example) informal burial societies. Even among the poorest households, only 7\% of adults participated in informal group insurance (stokvels) in 2002 (Ardington 2011).

Households undoubtedly combine different types of risk-sharing mechanisms to cope with local environmental shocks. The data do not allow me to conclusively rule out that these other differences in TBVC areas are part of the explanation for differences in the long-run health effects of drought. However, compared with the high prevalence of migrants attached to rural households (39 to 49\% of households had at least one migrant in 1996, Table 2), the alternative channels of informal insurance represent a far less prevalent "safety net" than access to migrant remittance income. Given the importance of remittance income in overall household budgets, and the larger responsiveness of remittances to drought in households with migrants, it is clear that access to migrant networks established during apartheid were an important part of how families were differentially able to cope with local droughts. Future work using micro-data on migrant outflows and remittance inflows to households during drought coupled with data on later-life health outcomes for the youngest members of these households may make it feasible to quantify how much access to migrant networks contributes to differences in long-run health effects of drought.

\section{Conclusions}

This paper provides new evidence on the long-term health consequences of early-life drought exposure in a context of highly prevalent local environmental shocks and restricted labor mobility. I estimate that early childhood drought exposure raises disability rates by about $4 \%$ for African males born into TBVC areas and lowers male cohort size by 2.6 percent. This is over and above the average negative impact of drought on disability and cohort size for exposed cohorts across all homelands. 
I describe how South Africa's apartheid policies erected higher barriers to spatial mobility out of the TBVC areas and show that access to migrant networks was worse in these areas during apartheid but improved after the repeal of legal restrictions on migration. I document the mechanism through which migrant networks helped families during drought by showing recent evidence that remittances respond to drought in households with migrant workers. While I cannot rule out other ways in which households in non-TBVC areas were able to differentially cope with drought during apartheid, the magnitude of differential exposure to migrant networks in TBVC and non-TBVC areas suggests an important role for spatial mobility in helping households to mitigate the long-run effects of local shocks. Mitigating long-run health effects of early-life shocks to the nutritional or disease environment is an important new avenue of research in the early-life health shocks literature.

While the policies of apartheid are unique to South Africa, restrictions on internal mobility occur throughout the world. Some barriers are institutional, as in China and the former Soviet Union. Others, particularly in Africa, are geographic in nature or related to inadequate transportation infrastructure. The development literature has noted the direct and immediate effects of limited spatial mobility on income volatility and has viewed spatial mobility as a form of insurance against economic shocks. My results highlight a new implication of migration barriers for health human capital accumulation over the long run. In environments prone to frequent local environmental shocks like drought, enhancing spatial mobility could generate large welfare gains through the health-protective effects of labor migration and related remittance behaviors. 


\section{References}

Alderman, Harold, Hans Hoogeven, and Mariacristina Rossi. 2009 "Preschool Nutrition and Subsequent School Attainment: Longitudinal Evidence from Tanzania.” Economic Development and Cultural Change Vol 57

Almond, Douglas. 2006 "Is the 1918 Influenza pandemic over? Long-term effects of in utero influenza exposure in the post-1940s US population”, Journal of Political Economy Vol. 114: 4

Almond, Douglas and Janet Currie. 2011a. "Human capital development before age 5”, in Handbook of Labor Economics, Vol. 4b. pp. 1315-1486. Elsevier

Almond, Douglas and Janet Currie. 2011b. “Killing me softly: The fetal origins hypothesis”, Journal of Economic Perspectives, Vol 25. No. 3, Summer pp. 153-172

Almond, Douglas and Bhashkar Mazumdar. 2011. "Health capital and the prenatal environment: The effect of Ramadan observance during pregnancy”, American Economic Journal: Applied Economics, Vol. 3. No. 4. pp.56-85.

Aguilar, Arturo and Marta Vicarelli. 2012. "El Niño and Mexican children: Medium-term effects of early-life weather shocks on cognitive and health outcomes”, Working paper.

Ardington, Cally, David Lam, Murray Leibbrandt and James Levinsohn. 2011. "Savings, insurance and debt over the post-apartheid period: A review of recent research", South African Journal of Economics, Vol. 72: 3

Ardington. E. M. 1999. "Demand or Support: What counts in rural finance? A case-study based on Mbongolwana KwaZulu Natal”, Research Report No 26, School of Development Studies, University of Natal-Durban

Banerjee, Abhijit, Esther Duflo, Gilles Postel-Vinay and Tim Watts. 2010. "Long-run health impacts of income shocks: Wine and Phylloxera in Nineteenth-Century France”, Review of Economics and Statistics, November. Vol. 94(2): 714-728

Barker, D. J. P. 1995. “Fetal Origins of Coronary Heart Disease”, British Medical Journal Vol. 311: $171-174$

Benson, Charlotte and Edward Clay. 2000. Drought: A Global Assessment, Vol. I, Routledge

Bertrand, Marianne, Esther Duflo and Sendhil Mullainathan, 2004. "How Much Should We Trust Differences-in-Differences Estimates?” The Quarterly Journal of Economics Vol. 119: 1 pp. 249-275

Besley, Timothy. 1995 “Savings, credit and insurance” in Handbook of Development Economics, Vol. 3. Jere Behrman and T.N. Srinivasan (eds). Chapter 36.

Bound, John, Charles Brown and Nancy Mathieowitz. 2001. "Measurement error in survey data" in Handbook of Econometrics. (ed) E.E. Learner and J.J. Heckman. Pp. 3705-3843, North Holland 
Bozzoli, Carlos, Angus Deaton and Climent Quintana-Domeque. 2009. “Adult height and childhood disease” Demography Vol. 46: 4, November, pp. 647-669

Brown, Barbara. 1987. "Facing the 'Black Peril': The politics of population control in South Africa”, Journal of Southern African Studies, Vol 13: 3

Bryan, Gharad, Shyamal Chowdhury and A. Mushfiq Mobarak, 2012 "Risk aversion and seasonal migration”, Mimeo, Yale University

Case, Anne and Christina Paxson, 2008. "Stature and status: height, ability, and labor market outcomes”, Journal of Political Economy Vol. 116 (3) pp. 499-532

Casale, Daniela and Dorrit Posel. 2006 “Migration and remittances in South Africa”, Mimeo, University of KwaZulu-Natal

Chen, Yuyu and Li-An Zhou. 2007. "The long-term health and economic consequences of the 1959-1961 famine in China”, Journal of Health Economics, Vol. 26 No. 4. pp. 659-681.

Clemens, Michael A. 2011. "Economics and Emigration: Trillion-Dollar Bills on the Sidewalk?” Journal of Economic Perspectives Vol. 25: 3 pp. 83-106

Coovadia, H., R. Jewkes, P. Barron, D. Sanders and D. McIntyre. 2009 "The health and health system of South Africa: historical roots of public health challenges”, The Lancet, September 5

Currie, Janet and Tom Vogl. 2013 "Early-Life Health and Adult Circumstance in Developing Countries”, Annual Review of Economics, Volume 5

De Beer, Cedric. 1984. The South African disease: Apartheid health and health services. Africa World Press: Trenton, New Jersey.

Desmet, Klaus and Esteban Rossi-Hansberg. 2012. “On the spatial economic impact of global warming”, NBER Working Paper 18546

Evans, Ivan. 1997. Bureaucracy and Race: Native Administration in South Africa. University Berkeley: University of California Press, http://ark.cdlib.org/ark:/13030/ft2n39n7f2/

Greenberg, Stanley and Hermann Giliomee. 1983. "Labour Bureaux and the African Reserves”, South African Labour Bulletin, 8(4): 37-50

Hoddinott, John, and Bill Kinsey. 2001. "Child Growth in the Time of Drought.” 2001. Oxford Bulletin of Economics and Statistics 63(4): 409-36

Jayachandran, Seema. 2006 "Selling labor low: Wage responses to productivity shocks in developing countries” Journal of Political Economy Vol 114: 3. Pp. 538-575

Jensen, Robert. 2000. “Agricultural Volatility and Investments in Children.” American Economic Review, Papers and Proceedings, 90(2): 399-404 
Kraemer, S. 2000. “The fragile male”, British Medical Journal Vol. 321: 7276. Pp. 1609-12

Le Roux, Noelien. 2009. "Seasonal maize yield simulations for South Africa using a multi-model ensemble system”, Unpublished thesis manuscript, University of Pretoria, April

Lemon, Anthony. 1984 "State control over the labor market in South Africa" International Political Science Review, Vol. 5, No. 2: 189-208

Lindeboom, Maarten, France Portrait and Gerard J. van den Berg. 2010 "Long-Run Longevity Effects of a Nutritional Shock Early in Life: The Dutch Potato Famine of 1846-1847” Journal of Health Economics, Vol 29, No. 5 pp 617-629

Maccini, Sharon and Dean Yang. 2009 "Under the weather: health, schooling and socioeconomic consequences of early-life rainfall”, American Economic Review 99(3): 1006-26

Mariotti, Martine. 2011 "Living standards in South Africa's former homelands", Working Paper, Department of Economics, Australian National University.

Martorell, R., L. Kettel Khan, and D.G. Schroeder. 1994 "Reversibility of stunting: Epidemiological findings in children from developing countries”, European Journal of Clinical Nutrition 48, S45\{S57\}

Martorell, Reynaldo. 1999. "The Nature of Child Malnutrition and its Long-Term Implications." Food and Nutrition Bulletin 20(3): 288-92.

Maylam, P. 1990. “The rise and decline of urban apartheid in South Africa”, African Affairs, 89: 57-84

McKee, T. B., N. Doesken and J. Kleist 1993 "The relationship of drought frequency and duration to time scales”, Preprints, 8th Conference on Applied Climatology, pp. 179-184. January 17-22, Anaheim, California

Meng, X. and Nancy Qian. 2009 "The long run health and economic consequences of famine on survivors: Evidence from China's great famine”, IZA Discussion Paper No. 2471.

Morten, Melanie. 2013 “Temporary migration and endogenous risk sharing in village India”, Mimeo, Yale University

Nattrass, Nicoli and Jeremy Seekings. 2011. "The economy and poverty in the twentieth century”, The Cambridge History of South Africa.Volume 2: 1885-1994. $1^{\text {st }}$ ed._Robert Ross, Anne Kelk Mager, Bill Nasson (editors). Cambridge: Cambridge University Press, Cambridge Histories Online: 518-572. http://dx.doi.org/10.1017/CHOL9780521869836.012 Accessed 01 October 2013

Posel, Dorrit. 2011. "Households and labour migration in post-apartheid South Africa”, Studies in Economics and Econometrics, Vol. 34: 3 
Price, Max. 1986. "Health care as an instrument of apartheid policy in South Africa”, Health Policy and Planning, 1(2): 158-170

Reed, Holly. 2012. "Moving across boundaries: Migration in South Africa, 1950-2000”, Demography, 50: 70-96

Rosenzweig, Mark and Oded Stark. 1989. “Consumption Smoothing, migration and marriage: Evidence from Rural India” Journal of Political Economy, Vol. 97: 4.

Rouault, M. and Y. Richard. 2005. "Spatial extent and intensity of droughts in Southern Africa" Geophysical Research Letters, Vol. 32: L15702, 4

Secretary for Bantu Administration and Development. 1967 "General Circular No. 25 - Settling of non-productive Bantu resident in European areas, in the homelands” in Maré, G. 1980

Population Relocation in South Africa, Appendix 5. South African Institute of Race Relations: Johannesburg

Savage, Michael. 1986 "The imposition of pass laws on the African population in South Africa 1916-1984”, African Affairs, Vol. 85: 339

Schroeder, Dirk, Martorell, Reynaldo, Rivera, Juan A., Ruela, Marie T. and Habicht, Jean-Pierre. 1995. "Age differences in the impact of nutritional supplementation on growth", The Journal of Nutrition, 125 (4 Supplement): 1051S-1059S

Simkins, Charles. 2011. "The evolution of the South African Population in the Twentieth Century”, The Cambridge History of South Africa.Volume 2: 1885-1994. $1^{\text {st }}$ ed._Robert Ross, Anne Kelk Mager, Bill Nasson (editors). Cambridge: Cambridge University Press, Cambridge Histories Online: 492-517. http://dx.doi.org/10.1017/CHOL9780521869836.012 1 October 2013

Simkins, Charles. 1983. Four essays on the past, present \& possible future of the distribution of the black population of South Africa, SALDRU, University of Cape Town

Townsend, Robert M. 1995 "Consumption insurance: An evaluation of risk-bearing systems in low-income countries”, Journal of Economic Perspectives Vol. 9: 3, Summer

Van den Berg, Gerard, Pia Pinger and Johannes Schoch. 2011 "Instrumental variable estimation of the causal effect of hunger early in life on health later in life”, IZA Discussion Paper No. 6110

Wilhite, D. 2001 Drought: A global assessment, vol. I, ch. "Drought as a natural hazard: Concepts and definitions”, Routledge

Wolpe, Harold. 1988 Race, class and the apartheid state. James Currey Press, London

Yang, Dean, and HwaJung Choi. 2007. "Are Remittances Insurance? Evidence from Rainfall Shocks in the Philippines.” World Bank Economic Review, 21(2): 219-48

Yang, Dean. 2011. “Migrant Remittances”, Journal of Economic Perspectives, Vol. 25: 3 pp. $129-52$ 


\section{FIGURE 1}

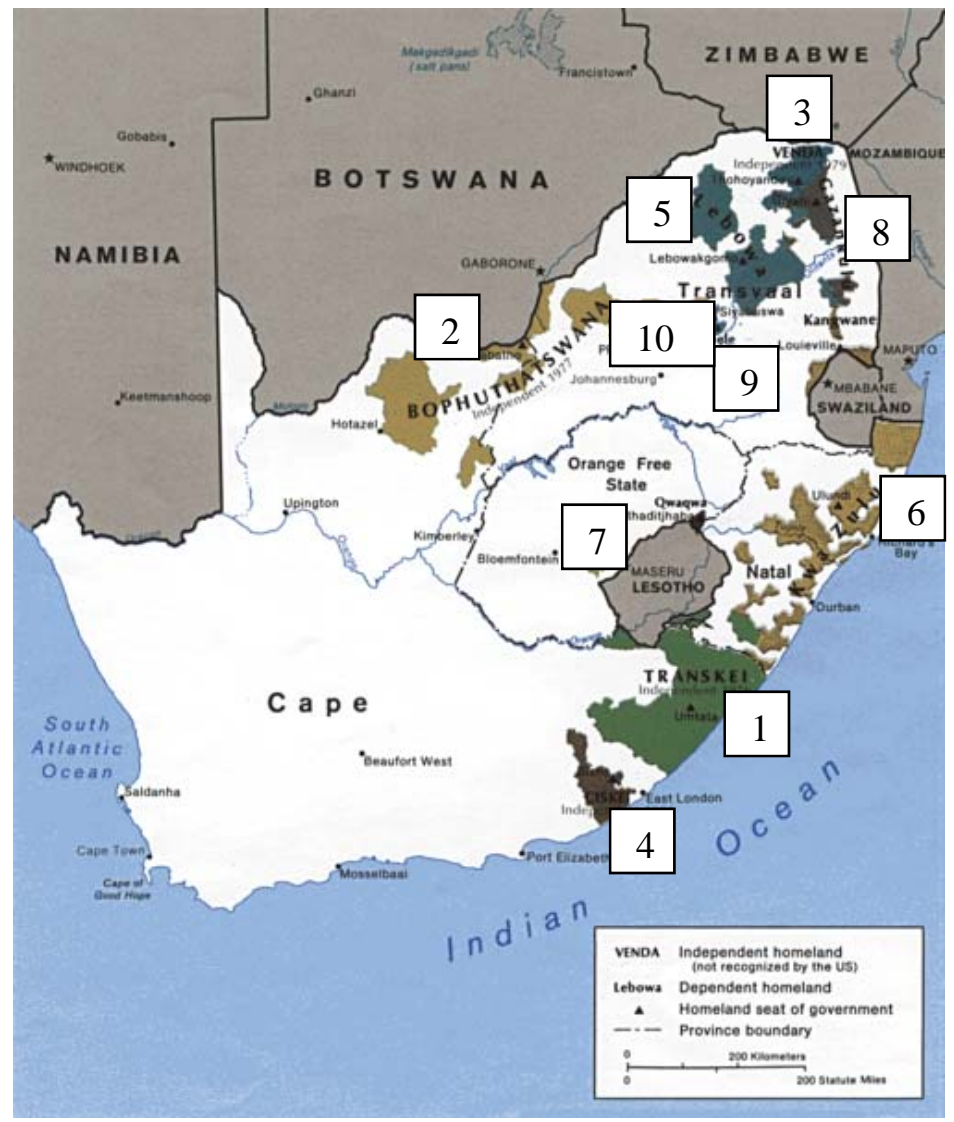

Source: Political map of South Africa 1986, Perry-Castañeda Library Map Collection, http://www.lib.utexas.edu/maps/south_africa.html, accessed July 2011. Homelands are (in order of establishment dates): TBVC areas: Transkei (1), Boputhatswana (2), Venda (3), Ciskei (4) and non-TBVC areas: Lebowa (5), KwaZulu (6), Qwaqwa (7), Gazankulu (8), Kangwane (9), KwaNdebele (10) 


\section{FIGURE 2}

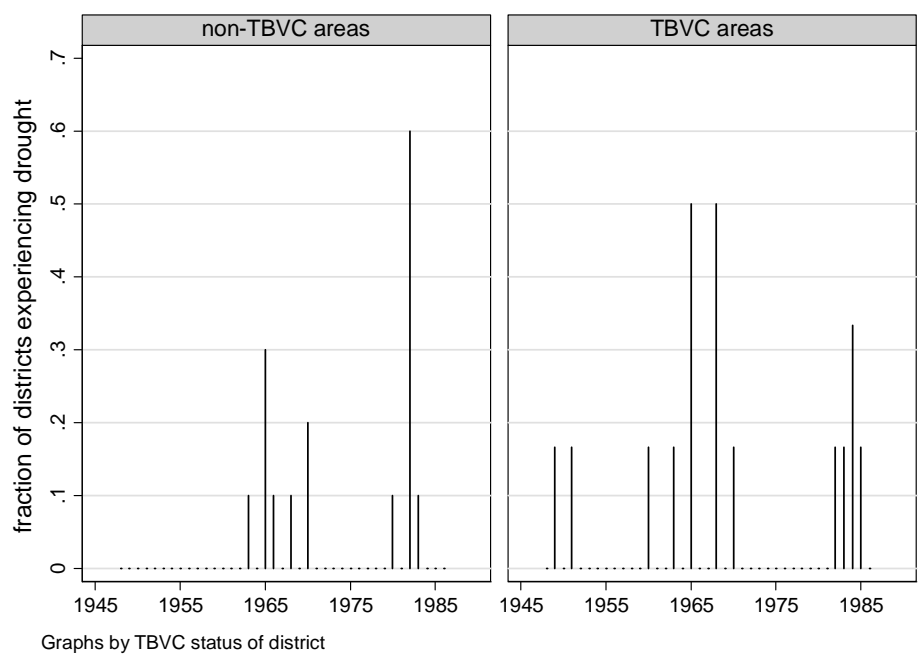

Figure 2 shows the fraction of South African homeland districts experiencing a drought annually between 1948 and 1986. The left hand panel shows drought in non-TBVC (less restricted) areas, the right hand panel for TBVC (more restricted) areas. The drought indicator is based on the Standardized Precipitation Index (SPI) as described in Data Appendix 1.

\section{FIGURE 3}

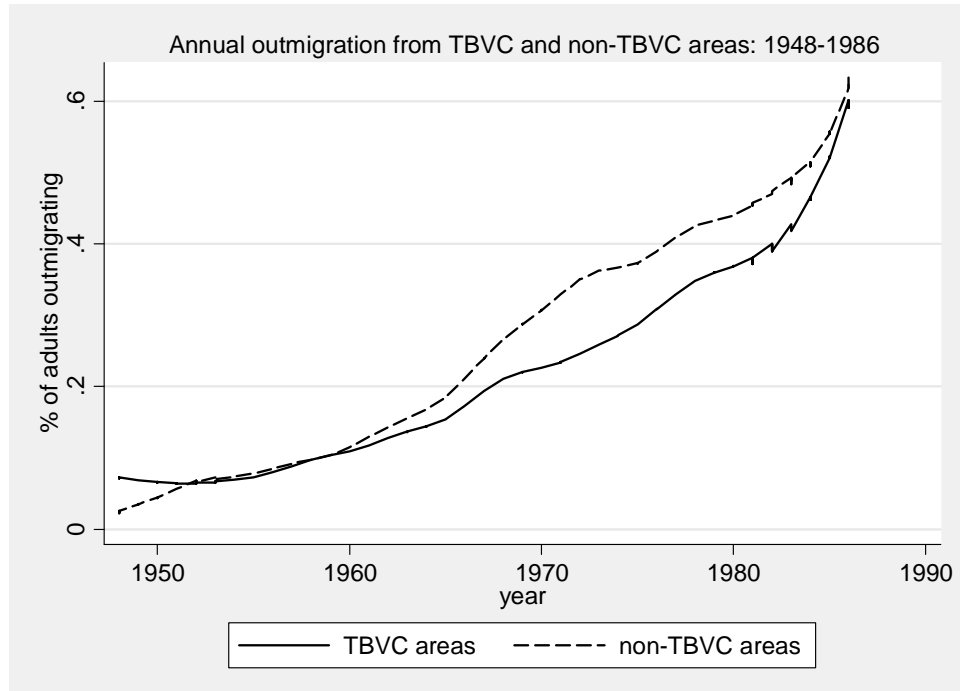

Figure 3 presents lowess-smoothed outmigration rates from TBVC and non-TBVC areas over time using Census data from 1948-1986. The y axis shows the average percent of adults who outmigrate from a district in a given year, across all districts. Kernel is Epanechnikov, bandwidth is 0.3 . 


\section{For Online Publication}

\section{Appendix 1: Data}

\section{Rainfall Data and Drought}

The South African Weather Service http://www.weathersa.co.za/web/ provided the raw historical rainfall data. These data contain monthly rainfall measures at the weather station level for over 1,600 weather stations across South Africa from 1920 to 2009. I spatially match the GIS locations of rainfall stations to corresponding district boundaries and aggregate rainfall totals to the district-year level.

To create a measure of drought, I construct the Standardized Precipitation Index (SPI) at the district and year level (McKee, Doesken and Kleist 1993). The SPI measures the probability of observing a recent rainfall event based on the distribution of all rainfall events for a given time scale and place. Since rainfall is not normally distributed, the SPI procedure calls for a gamma distribution to be fit to the empirical data distributions. I fit a gamma distribution to the annual total rainfall of each district. and generate estimates of the scale and location parameters for district-specific rainfall patterns. For each year in the data, and the district-specific gamma distribution, I compute the probability of observing the total rainfall that was measured in each year and translate this into a normally distributed random variable using the normal CDF. This number is the district-year-specific SPI, where positive numbers reflect above-average rainfall and negative values reflect below-average rainfall. The positive relationship between log rainfall and the SPI measure across all districts is shown in Appendix Figure 1.

Following the climatological literature (e.g. McKee et al 1993) I define an indicator $D R O U G H T_{d t}$ for each district $(d)$ and year $(t)$ that takes a value of 1 when the SPI is less than 1.5, and 0 otherwise. Appendix Figure 2 shows lowess-smoothed graphs of the district level mean SPI values across TBVC and non-TBVC areas for the years 1948 to 1986.

There is a tight link between the SPI measure and South African maize production. Using province-level data from the South African Maize Board for the period 1964 to 1984 and for the commercial maize-growing provinces (Transvaal and the Orange Free State), I estimate the relationship between the SPI measure and maize yields. Appendix Figure 3 shows the lowesssmoothed relationship between the log of South Africa's annual maize output (in tons) against the Spatial Precipitation Index using an Epanechnikov kernel with a 0.5 bandwidth. This positive relationship is asymmetric. Output appears more sensitive to low values of the SPI than it is to higher, positive values of the SPI. Figure 3 suggests that drought in particular captures an important negative productivity shock in agriculture. 


\section{Appendix Figure 1}

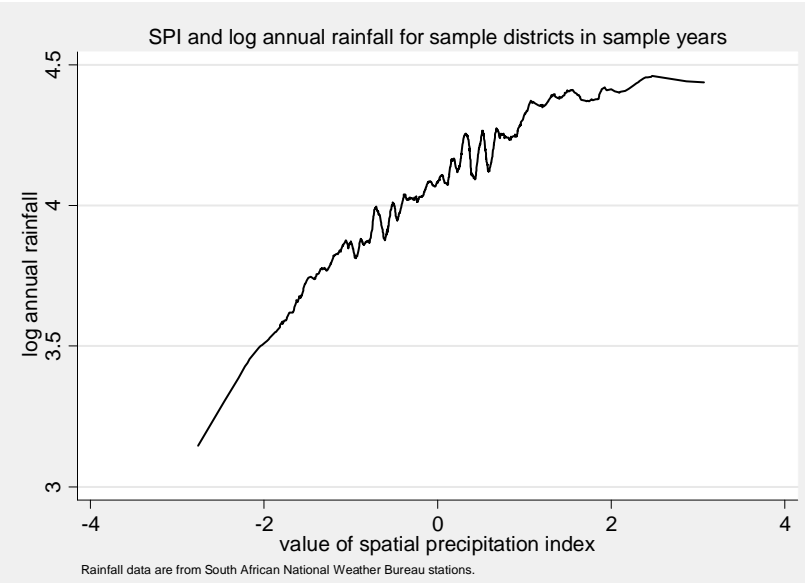

\section{Appendix Figure 2}

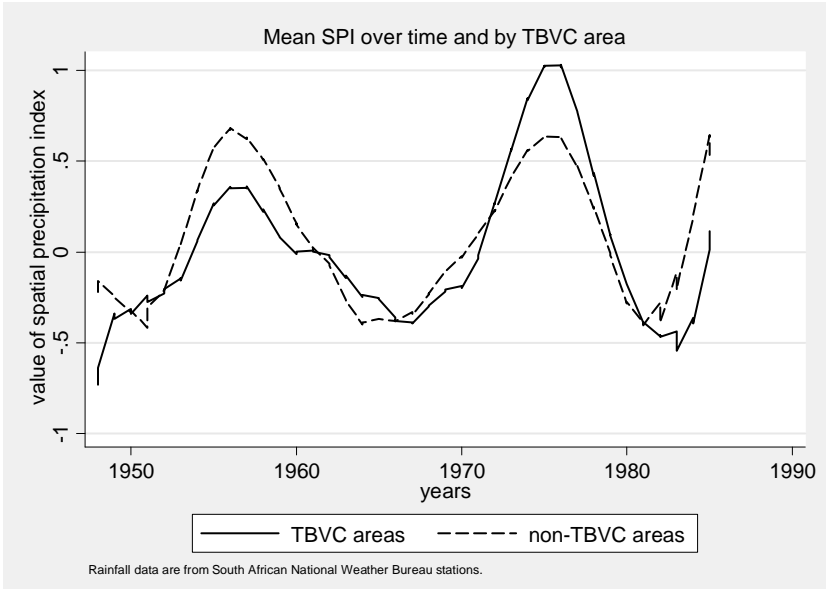

\section{Appendix Figure 3}






\section{Homeland Boundary Data and the TBVC assignment}

GIS data on sub-national boundaries for the 1996 and 2001 Census were obtained from Statistics South Africa (www.statssa.gov.za). I use the 2001 district council Census boundaries as the main geographic unit of observation since these areas are large enough to treat as distinct local labor markets and contain sufficient population in each year to make aggregation feasible. ${ }^{1}$

To define which of these districts belong to former homeland areas, I obtained online maps of the ten homelands with the predominant map dated 1986 (see Figure 1 in the main text). I overlaid these homeland maps onto Census boundaries and, where there was overlap, assigned districts to homelands. I created an indicator $T B V C_{d}$ that takes a value of 1 if a district overlapped with any of the TBVC homelands, and is 0 for those districts overlapping the remaining six homelands. ${ }^{2}$ Of the 53 district councils in South Africa, 16 of them (30\%) fall into prior rural homeland areas. Of these 16 areas, six fall in the former TBVC areas and the remaining 10 fall in the non-TBVC areas.

\section{1996 Census Data}

The 10\% sample of individual records from the 1996 South African Census was obtained from Statistics South Africa (www.statssa.gov.za).

\section{i. $\quad$ Migration variables}

Migration is difficult to measure well using household survey data. The benefit of using Census data is that it provides comprehensive coverage of migrant groups across the country, unlike general household surveys that draw from a subset of districts. The coverage of the Census also allows aggregation of migration data to broader geographic units (for our purposes, the district level).

I use information from Census questions: "Where do you live now? Where did you live before this? What year did you move here?” to construct migration variables. Specifically, I define:

- The district of current residence

- The district of former residence: this is the same as district of current residence for individuals who report never having moved, for individuals who have moved since the end of apartheid (1994-1996), for individuals who reported moving during childhood to their current residence, and for those who report moving within a district An indicator for whether a person moved before 1994 (the end of apartheid) and during their adult lives. This indicator is 1 if a person's former residence differs from their current residence and if they report the year they moved to their current residence.

\footnotetext{
${ }^{1}$ Magisterial districts are too small to contain sufficient population and rainfall measurements for my analysis.

${ }^{2}$ TBVC stands for Transkei, Boputhatswana, Venda and the Ciskei.
} 
The sample is restricted to African adults aged 18 and older in 1996 who report a current (for never movers) or prior residence (for movers) in South Africa that is predominantly rural and located in one of the former homeland areas. I eliminate individuals reporting a current residence (for never movers) or a prior residence (for movers) in a district outside of any of the homelands, and those who report living in (for never movers) or formerly living in (for movers) districts outside of South Africa. Less than 1\% of the sample has a usual residence outside South Africa and less than $5 \%$ have a prior residence outside of South Africa. Of the remaining sample of adults who report a former residence (for movers) or current residence (for never movers) located in rural South Africa, 97\% have complete information on current and former district of residence and the year of moving to current residence. For the 3\% who report a current residence and no information about year of moving, I assign them to be non-movers.

Using the migration variables, I construct a pseudo-panel dataset of individual-year observations capturing where each person lived in each year. This dataset indicates whether a person moved out of a given district in any given year, based on their "last move” information and allows me to observe the total number of adults (ages 18 and over) in each district in each year between 1948 and 1986 and the number who move away from each district in each year. I collapse the data to district-year level and generate the percent of adults living in each district that migrated away in each year. I use this district-year level dataset to describe historical outmigration from each district in each year in Tables 1, 2 and Figure 2.

\section{ii. Health, fertility and population outcomes}

For the disability analysis, and for the analysis of cohort size and sex composition, I use the sample of African adults who lived in any of the former homeland areas between 1948 and 1986. I match the cross-sectional data on outcomes at the individual level to the drought data on year of birth and prior district.

Note that the Census does not capture place of birth information, so I assume that a person's prior residence is their birth district. This means that birth district is potentially misclassified for people who move multiple times. ${ }^{3}$

For the analysis of fertility and child mortality outcomes, I restrict the sample to African women aged 40 to 60 in 1996 who have completed childbearing. I create a variable that represents the fraction of their childbearing years (ages 15-40) that they experienced drought. I assign drought exposure at the district level using the prior district reported by these women.

\footnotetext{
${ }^{3}$ Data from the 2007 South African Community Survey and the 2007 Cape Area Panel Study indicate that the fraction of Africans who move more than once in the past five years is between 0.01 and 0.13 respectively. The 2007 Community Survey collects data on more than 300,000 African adults including their province of current and prior residences. The 2007 Cape Area Panel Survey is a sample of young adults (ages 24-33) drawn from a province with a highly mobile population, hence the higher rates of misclassification. Older data from the 1997 October Household Survey corroborates these numbers: among African adults aged 15 and older in 1986, only about 4\% of them report moving at all across magisterial districts in any year prior to 1986. And, under $1 \%$ report multiple crossdistrict moves during the apartheid period.
} 


\section{Baseline District-level control variables}

To control for key district level variables that could contribute to differential responses of disability rates to drought events, I create:

- District-level population density recorded in the 1946 South African Census. These data were digitized from hardcopies of Census aggregate reports and matched to later district boundaries

- The straight-line distance (in kilometers) from the midpoint of each district polygon to the nearest large city. Distances were calculated using 1996 Census maps in ArcGIS version 10

- A district's median score on the FAO's maize suitability index. This index captures how suitability land is for maize production at a fine grid level. I use these values to create the median value of the suitability index across all points in given district in ArcGIS. Low values of this number represent greater suitability of the soil for maize production

\section{References}

McKee, T. B., N. Doesken and J. Kleist 1993 "The relationship of drought frequency and

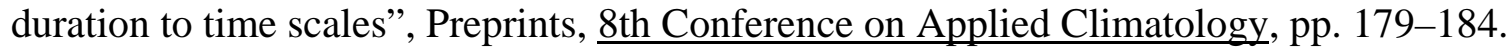
January 17-22, Anaheim, California 
Table 1: Summary Statistics for TBVC and Non-TBVC Areas

\begin{tabular}{|c|c|c|c|c|c|c|c|}
\hline & $\begin{array}{c}\text { Sample means } \\
\text { for all } \\
\text { homelands }\end{array}$ & $\begin{array}{l}\text { TBVC sample } \\
\text { means }\end{array}$ & $\begin{array}{c}\text { Non-TBVC } \\
\text { sample means }\end{array}$ & $\begin{array}{l}p \text {-value of } \\
\text { difference }\end{array}$ & $\mathrm{N}$ & Min. & Max. \\
\hline \multicolumn{8}{|c|}{ Panel A: Individual-level Census data } \\
\hline \multicolumn{8}{|l|}{ Cohorts born 1948-1986 } \\
\hline Drought in year of birth & 0.067 & 0.073 & 0.062 & 0.720 & 655,532 & 0 & 1 \\
\hline Fraction of infancy (in utero to age 4) in drought & 0.074 & 0.081 & 0.069 & 0.214 & 655,532 & 0 & 0.4 \\
\hline Age & 23.742 & 23.775 & 23.714 & 0.285 & 655,532 & 10 & 48 \\
\hline Female & 0.545 & 0.543 & 0.546 & 0.006 & 655,532 & 0 & 1 \\
\hline Years of education & 6.356 & 6.426 & 6.295 & 0.202 & 641,575 & 0 & 15 \\
\hline Any serious disability & 0.052 & 0.054 & 0.051 & 0.012 & 655,532 & 0 & 1 \\
\hline Number of serious disabilities & 0.057 & 0.059 & 0.054 & 0.000 & 655,532 & 0 & 4 \\
\hline Sight disability & 0.023 & 0.024 & 0.022 & 0.003 & 655,532 & 0 & 1 \\
\hline Speech/hearing disability & 0.011 & 0.012 & 0.011 & 0.006 & 655,532 & 0 & 1 \\
\hline Physical disability & 0.014 & 0.015 & 0.014 & 0.148 & 655,532 & 0 & 1 \\
\hline Mental disability & 0.007 & 0.008 & 0.007 & 0.000 & 655,532 & 0 & 1 \\
\hline \multicolumn{8}{|l|}{ Female cohorts age 40-60 in 1996} \\
\hline Number of children ever born & 4.793 & 4.909 & 4.688 & 0.000 & 79,532 & 0 & 23 \\
\hline Fraction of child-bearing years in drought & 0.071 & 0.076 & 0.067 & 0.023 & 79,532 & 0 & 0.4 \\
\hline \multicolumn{8}{|c|}{ Panel B: District level data } \\
\hline Population density in 1946 (per km²) & 48.237 & 38.207 & 54.255 & 0.43 & 16 & 15 & 137 \\
\hline Remoteness: Distance to nearest large city (kms) & 33.247 & 36.466 & 31.316 & 0.62 & 16 & 7 & 77 \\
\hline Agricultural potential: maize suitability index (median) & 6.563 & 7.000 & 6.300 & 0.17 & 16 & 5 & 9 \\
\hline Number of districts & 16 & 6 & 10 & & & & \\
\hline Number of birth years & 39 & 39 & 39 & & & & \\
\hline
\end{tabular}


Table 2: Access to Migrant Networks in TBVC and Non-TBVC Areas

\begin{tabular}{|c|c|c|c|c|c|}
\hline & $\begin{array}{c}\text { All } \\
\text { homelands }\end{array}$ & $\begin{array}{c}\text { TBVC } \\
\text { homelands }\end{array}$ & $\begin{array}{l}\text { Non-TBVC } \\
\text { homelands }\end{array}$ & Difference & $p$ value \\
\hline \multicolumn{6}{|l|}{ During mobility restrictions 1948-1986 } \\
\hline Annual adult outmigration rate & 0.002 & 0.002 & 0.003 & -0.0004 & 0.001 \\
\hline Cumulative outmigrants/Adult population in 1996 & 0.101 & 0.090 & 0.111 & -0.021 & 0.002 \\
\hline \multicolumn{6}{|l|}{ After repeal of mobility restrictions 1987-1993 } \\
\hline Cumulative outmigrants/Adult population in $1996^{\wedge}$ & 0.142 & 0.144 & 0.141 & 0.003 & 0.718 \\
\hline Share of households with any remittances $\sim$ & 0.452 & 0.390 & 0.499 & -0.109 & 0.000 \\
\hline Mean monthly remittances in households with migrants (ZAR) & 220.188 & 207.224 & 228.003 & -20.779 & 0.141 \\
\hline Share of monthly household income from remittances & 0.261 & 0.265 & 0.256 & 0.009 & 0.276 \\
\hline
\end{tabular}

Notes: Means are from 1996 Census data or from the 1993 SALDRU household survey data ( ). Samples are restricted to African households in ex-homeland areas. Census variables measured at district level between 1948-1986, or 1987-1993. SALDRU variables measured at household level in 1993 and weighted using population weights. $p$-values for differences in means are shown with robust standard errors. Cumulative outmigrants/Adult population is the number of total adult migrations recorded using last move data for relevant time period, divided by the total adult population in the district in 1996. 


\begin{tabular}{|c|c|c|c|c|c|c|}
\hline & \multicolumn{2}{|c|}{ Full sample } & \multicolumn{2}{|c|}{ Male sample } & \multicolumn{2}{|c|}{ Female sample } \\
\hline & (1) & $(2)$ & (3) & (4) & (5) & (6) \\
\hline & \multicolumn{6}{|c|}{ Panel A: Any disability } \\
\hline Fraction early childhood in drought & $\begin{array}{c}0.002 * * \\
(0.0004)\end{array}$ & & $\begin{array}{c}0.003^{* * *} \\
(0.001)\end{array}$ & & $\begin{array}{c}0.001^{* * *} \\
(0.0004)\end{array}$ & \\
\hline Drought in birth year & & $\begin{array}{l}0.003 * \\
(0.002)\end{array}$ & & $\begin{array}{c}0.004 \\
(0.003)\end{array}$ & & $\begin{array}{c}0.002 \\
(0.002)\end{array}$ \\
\hline Birth year, district FE & $\mathrm{Y}$ & $\mathrm{Y}$ & $\mathrm{Y}$ & $\mathrm{Y}$ & $\mathrm{Y}$ & $\mathrm{Y}$ \\
\hline District controls*Drought & $\mathrm{N}$ & $\mathrm{Y}$ & $\mathrm{N}$ & $\mathrm{Y}$ & $\mathrm{N}$ & $\mathrm{Y}$ \\
\hline Mean of outcome & 0.053 & 0.053 & 0.051 & 0.051 & 0.053 & 0.053 \\
\hline \multirow[t]{2}{*}{$\mathrm{N}$} & 655,532 & 655,532 & 298,475 & 298,475 & 357,057 & 357,057 \\
\hline & \multicolumn{6}{|c|}{ Panel B: Number of disabilities } \\
\hline Fraction early childhood in drought & $\begin{array}{c}0.002^{* * *} \\
(0.001)\end{array}$ & & $\begin{array}{c}0.003^{* *} \\
(0.001)\end{array}$ & & $\begin{array}{l}0.002^{* *} \\
(0.001)\end{array}$ & \\
\hline Drought in birth year & & $\begin{array}{c}0.004^{* *} \\
(0.002)\end{array}$ & & $\begin{array}{l}0.006^{*} \\
(0.003)\end{array}$ & & $\begin{array}{c}0.003 \\
(0.002)\end{array}$ \\
\hline Birth year, district FE & $\mathrm{Y}$ & $\mathrm{Y}$ & $\mathrm{Y}$ & $\mathrm{Y}$ & $\mathrm{Y}$ & $\mathrm{Y}$ \\
\hline District controls*Drought? & $\mathrm{N}$ & $\mathrm{Y}$ & $\mathrm{N}$ & $\mathrm{Y}$ & $\mathrm{N}$ & $\mathrm{Y}$ \\
\hline Mean of outcome & 0.057 & 0.057 & 0.055 & 0.055 & 0.058 & 0.058 \\
\hline \multirow[t]{2}{*}{$\mathrm{N}$} & 655,532 & 655,532 & 298,475 & 298,475 & 357,057 & 357,057 \\
\hline & \multicolumn{6}{|c|}{ Panel C: Log cohort size } \\
\hline Fraction early childhood in drought & $\begin{array}{l}-0.007 \\
(0.005)\end{array}$ & & $\begin{array}{l}-0.011^{*} \\
(0.006)\end{array}$ & & $\begin{array}{l}-0.004 \\
(0.005)\end{array}$ & \\
\hline Drought in birth year & & $\begin{array}{l}-0.011 \\
(0.038)\end{array}$ & & $\begin{array}{l}-0.020 \\
(0.049)\end{array}$ & & $\begin{array}{l}-0.004 \\
(0.032)\end{array}$ \\
\hline Birth year, district FE & $\mathrm{Y}$ & $\mathrm{Y}$ & $\mathrm{Y}$ & $\mathrm{Y}$ & $\mathrm{Y}$ & $\mathrm{Y}$ \\
\hline District controls*Drought? & $\mathrm{N}$ & $\mathrm{Y}$ & $\mathrm{N}$ & $\mathrm{Y}$ & $\mathrm{N}$ & $\mathrm{Y}$ \\
\hline Mean of outcome & 6.77 & 6.77 & 5.94 & 5.94 & 6.18 & 6.18 \\
\hline $\mathrm{N}$ & 624 & 624 & 624 & 624 & 624 & 624 \\
\hline
\end{tabular}

Robust standard errors clustered on the year of birth. Levels of significance: $p<0.01^{* * *}, \mathrm{p}<0.05^{* *}, \mathrm{p}<0.1^{*}$. Drought exposure is a binary variable constructed using values of the Spatial Precipitation Index; fraction of infancy in drought is the fraction of years from in utero period to age 4 that the drought indicator equals one. Sample restricted to 1996 Census data on individuals born between 1948 and 1986. Coefficient on fraction early childhood in drought evaluated at the mean of the drought exposure variable (0.074 in Panels A and B; 0.06 in Panel C). All regressions contain a full set of birth year and district fixed effects. 
Table 4: Heterogeneous Effects of Drought Exposure in Early Childhood on Prevalence and Number of Disabilities Later in Life, 1948-1986

\begin{tabular}{|c|c|c|c|c|c|c|c|c|c|c|c|c|}
\hline \multirow{3}{*}{ Dependent variable: } & \multicolumn{4}{|c|}{ Full sample $[N=655,532]$} & \multicolumn{4}{|c|}{ Male sample $[N=298,475]$} & \multicolumn{4}{|c|}{ Female sample $[N=357,057]$} \\
\hline & \multicolumn{2}{|c|}{ Any disability } & \multicolumn{2}{|c|}{ Num. disabilities } & \multicolumn{2}{|c|}{ Any disability } & \multicolumn{2}{|c|}{ Num. disabilities } & \multicolumn{2}{|c|}{ Any disability } & \multicolumn{2}{|c|}{ Num. disabilities } \\
\hline & $(1)$ & $(2)$ & $(3)$ & (4) & $(5)$ & $(6)$ & $(7)$ & $(8)$ & $(9)$ & $(10)$ & $(11)$ & $(12)$ \\
\hline Fraction early childhood in drought & $\begin{array}{l}0.001^{* *} \\
(0.000)\end{array}$ & & $\begin{array}{l}0.002 * * \\
(0.001)\end{array}$ & & $\begin{array}{c}0.002 * * \\
(0.001)\end{array}$ & & $\begin{array}{l}0.002^{* *} \\
(0.001)\end{array}$ & & $\begin{array}{l}0.001^{*} \\
(0.001)\end{array}$ & & $\begin{array}{l}0.001 * \\
(0.001)\end{array}$ & \\
\hline Fraction early childhood in drought*TBVC & $\begin{array}{l}0.001^{*} \\
(0.000)\end{array}$ & & $\begin{array}{l}0.001^{* *} \\
(0.000)\end{array}$ & & $\begin{array}{c}0.002^{* * *} \\
(0.001)\end{array}$ & & $\begin{array}{l}0.002^{* *} \\
(0.001)\end{array}$ & & $\begin{array}{l}0.0000 \\
(0.001)\end{array}$ & & $\begin{array}{l}0.0006 \\
(0.001)\end{array}$ & \\
\hline Drought in birth year & & $\begin{array}{c}0.001 \\
(0.002)\end{array}$ & & $\begin{array}{c}0.002 \\
(0.002)\end{array}$ & & $\begin{array}{l}-0.001 \\
(0.003)\end{array}$ & & $\begin{array}{l}0.0003 \\
(0.004)\end{array}$ & & $\begin{array}{l}0.0029 * \\
(0.002)\end{array}$ & & $\begin{array}{l}0.0028^{*} \\
(0.002)\end{array}$ \\
\hline Drought in birth year*TBVC & & $\begin{array}{c}0.004 \\
(0.002)\end{array}$ & & $\begin{array}{c}0.005 \\
(0.003)\end{array}$ & & $\begin{array}{c}0.0099 * * \\
(0.004)\end{array}$ & & $\begin{array}{l}0.0098^{*} \\
(0.005)\end{array}$ & & $\begin{array}{l}-0.001 \\
(0.002)\end{array}$ & & $\begin{array}{l}0.0001 \\
(0.002)\end{array}$ \\
\hline $\begin{array}{l}\text { Birth year, district } \mathrm{FE} \\
\boldsymbol{p} \text {-values for F-tests }\end{array}$ & $\mathrm{Y}$ & $\mathrm{Y}$ & $\mathrm{Y}$ & $\mathrm{Y}$ & $\mathrm{Y}$ & $\mathrm{Y}$ & $\mathrm{Y}$ & $\mathrm{Y}$ & $\mathrm{Y}$ & $\mathrm{Y}$ & $\mathrm{Y}$ & $\mathrm{Y}$ \\
\hline All drought parameters jointly $=0$ & 0.00 & 0.02 & 0.00 & 0.06 & 0.02 & 0.01 & 0.03 & 0.12 & 0.02 & 0.16 & 0.01 & 0.22 \\
\hline Sum of Drought and Drought*TBVC $=0$ & 0.00 & 0.01 & 0.00 & 0.02 & 0.01 & 0.10 & 0.01 & 0.15 & 0.01 & 0.50 & 0.00 & 0.25 \\
\hline Mean of outcome & 0.052 & 0.052 & 0.056 & 0.056 & 0.051 & 0.051 & 0.055 & 0.055 & 0.053 & 0.053 & 0.057 & 0.057 \\
\hline
\end{tabular}

Robust standard errors clustered on the year of birth. Levels of significance: $p<0.01^{* * *}, p<0.05^{* *}, p<0.1^{*}$. Drought exposure is a binary variable constructed using values of the Spatial Precipitation Index; fraction of infancy in drought is the fraction of years from in utero period to age 4 that the drought indicator equals one ; TBVC indicates whether an individual reports a prior district is TBVC or not. Sample restricted to 1996 Census data on individuals born between 1948 and 1986. Coefficient on fraction early childhood in drought evaluated at the mean of this variable (0.074). 
Table 5: Heterogeneous Effects of Drought Exposure in Early Childhood on Prevalence and Number of Male Disabilities Later in Life - Robustness Checks

\begin{tabular}{|c|c|c|c|c|c|c|c|c|}
\hline \multirow[t]{2}{*}{ Dependent variable: } & \multicolumn{4}{|c|}{ Any disability } & \multicolumn{4}{|c|}{ Num. Disabilities } \\
\hline & $(1)$ & $(2)$ & (3) & (4) & $(5)$ & (6) & (7) & (8) \\
\hline Fraction early childhood in drought & $\begin{array}{c}0.002 * * \\
(0.001)\end{array}$ & & $\begin{array}{c}0.004 * * \\
(0.002)\end{array}$ & & $\begin{array}{l}0.002^{* *} \\
(0.001)\end{array}$ & & $\begin{array}{l}0.005^{* *} \\
(0.002)\end{array}$ & \\
\hline Fraction early childhood in drought*TBVC & $\begin{array}{c}0.002 * * \\
(0.001)\end{array}$ & & $\begin{array}{c}0.003^{* *} \\
(0.001)\end{array}$ & & $\begin{array}{l}0.002^{* *} \\
(0.001)\end{array}$ & & $\begin{array}{c}0.003^{* *} \\
(0.001)\end{array}$ & \\
\hline Drought in birth year & & $\begin{array}{l}-0.001 \\
(0.003)\end{array}$ & & $\begin{array}{l}-0.008 \\
(0.009)\end{array}$ & & $\begin{array}{c}0.000 \\
(0.004)\end{array}$ & & $\begin{array}{l}-0.011 \\
(0.011)\end{array}$ \\
\hline Drought in birth year*TBVC & & $\begin{array}{c}0.0099 * * \\
(0.004)\end{array}$ & & $\begin{array}{c}0.009 * * \\
(0.004)\end{array}$ & & $\begin{array}{c}0.0098 * \\
(0.005)\end{array}$ & & $\begin{array}{l}0.009 * \\
(0.005)\end{array}$ \\
\hline Birth district, year fixed effects & $\mathrm{Y}$ & $\mathrm{Y}$ & Y & $\mathrm{Y}$ & $\mathrm{Y}$ & Y & Y & Y \\
\hline $\begin{array}{l}\text { District controls interacted with drought measures } \\
\text { p-values for F-tests }\end{array}$ & $\mathrm{N}$ & $\mathrm{N}$ & $\mathrm{Y}$ & $\mathrm{Y}$ & $\mathrm{N}$ & $\mathrm{N}$ & $\mathrm{Y}$ & Y \\
\hline All drought parameters jointly $=0$ & 0.02 & 0.01 & 0.00 & 0.07 & 0.03 & 0.12 & 0.00 & 0.18 \\
\hline Sum of Drought and Drought $*$ TBVC $=0$ & 0.01 & 0.10 & 0.00 & 0.92 & 0.01 & 0.15 & 0.00 & 0.89 \\
\hline All district interactions with Drought $=0$ & & & 0.00 & 0.11 & & & 0.00 & 0.04 \\
\hline Mean of outcome & 0.051 & 0.051 & 0.051 & 0.051 & 0.055 & 0.055 & 0.055 & 0.055 \\
\hline
\end{tabular}

Robust standard errors clustered on the year of birth. Levels of significance: $p<0.01^{* * *}, \mathrm{p}<0.05^{* *}, \mathrm{p}<0.1^{*}$. Drought exposure is a binary variable constructed using values of the Spatial Precipitation Index; fraction of infancy in drought is the fraction of years from in utero period to age 4 that the drought indicator equals one; TBVC indicates whether an individual reports their prior district is TBVC or not. District variables (population density in 1946, distance to the nearest city in kilometers, and the maize suitability index where higher numbers indicate lower suitability) are each interacted with the relevant drought measure. Sample restricted to 1996 Census data on males born between 1948 and 1986 ( $\mathrm{N}=298,475)$. Coefficient on fraction early childhood in drought evaluated at the mean of this variable (0.074). 
Table 6: Heterogeneous Effects of Drought Exposure in Early Childhood on Cohort Size, 1948-1986

\begin{tabular}{|c|c|c|c|c|c|c|}
\hline \multirow[t]{2}{*}{ Dependent variable } & \multicolumn{2}{|c|}{ Ln cohort size } & \multicolumn{2}{|c|}{ Ln males } & \multicolumn{2}{|c|}{ Ln females } \\
\hline & $(1)$ & $(2)$ & (3) & $(4)$ & $(5)$ & (6) \\
\hline Fraction early childhood in drought & $\begin{array}{l}-0.024 \\
(0.023)\end{array}$ & & $\begin{array}{l}-0.040 \\
(0.031)\end{array}$ & & $\begin{array}{l}-0.011 \\
(0.020)\end{array}$ & \\
\hline Fraction early childhood in drought*TBVC & $\begin{array}{c}-0.02 * * * \\
(0.007)\end{array}$ & & $\begin{array}{c}-0.026^{* * *} \\
(0.010)\end{array}$ & & $\begin{array}{c}-0.016^{* * *} \\
(0.006)\end{array}$ & \\
\hline Drought in birth year & & $\begin{array}{l}-0.009 \\
(0.159)\end{array}$ & & $\begin{array}{l}-0.062 \\
(0.201)\end{array}$ & & $\begin{array}{r}0.036 \\
(0.133)\end{array}$ \\
\hline Drought in birth year*TBVC & & $\begin{array}{c}-0.048 \\
(0.062)\end{array}$ & & $\begin{array}{l}-0.079 \\
(0.081)\end{array}$ & & $\begin{array}{l}-0.027 \\
(0.053)\end{array}$ \\
\hline Birth year, district FE & $\mathrm{Y}$ & $\mathrm{Y}$ & $\mathrm{Y}$ & $\mathrm{Y}$ & $\mathrm{Y}$ & $\mathrm{Y}$ \\
\hline $\begin{array}{l}\text { District variables*Drought controls } \\
\text { p-values for F-tests }\end{array}$ & $\mathrm{Y}$ & $\mathrm{Y}$ & $\mathrm{Y}$ & $\mathrm{Y}$ & $\mathrm{Y}$ & $\mathrm{Y}$ \\
\hline All Drought, Drought*TBVC parameters jointly $=0$ & 0.02 & 0.485 & 0.03 & 0.459 & 0.03 & 0.617 \\
\hline $\mathrm{N}$ & 624 & 624 & 624 & 624 & 624 & 624 \\
\hline
\end{tabular}

Robust standard errors clustered on the year of birth. $\mathrm{p}<0.01^{* * *}, \mathrm{p}<0.05^{* *}, \mathrm{p}<0.1^{*}$. District controls described in summary statistics table. Regressions are estimated using observations aggregated to the year of birth-first district level. Sample is restricted to cohorts born 19481986 (ages 10-48) in 1996. Coefficients in 1, 3 and 5 are weighted by average fraction of early childhood years in drought $(0.06)$. 
Table 7: Heterogeneous Effects of Drought Exposure During Childbearing Years on Fertility Outcomes of African Women Who Have Completed Childbearing by 1996

Dependent variable Number of children ever born

\begin{tabular}{lcccc} 
& $\begin{array}{c}\text { All } \\
\text { education } \\
\text { levels } \\
(1)\end{array}$ & $\begin{array}{c}\text { No } \\
\text { education }\end{array}$ & $\begin{array}{c}\text { Some } \\
\text { primary } \\
\text { school }\end{array}$ & $\begin{array}{c}\text { Some high } \\
\text { school }\end{array}$ \\
\hline Fraction years in drought (ages 15-40) & 0.001 & 0.109 & -0.138 & $-0.273^{* * *}$ \\
& $(0.061)$ & $(0.092)$ & $(0.100)$ & $(0.083)$ \\
Fraction years in drought (ages 15-40)*TBVC & $-0.228^{* * *}$ & $-0.283^{* * *}$ & -0.149 & 0.096 \\
& $(0.084)$ & $(0.107)$ & $(0.188)$ & $(0.100)$ \\
& Y & Y & Y & Y \\
Birth year, district FE & 70,836 & 33,312 & 15,852 & 19,952 \\
& 4.79 & 4.96 & 5.11 & 4.35 \\
\hline N & & & \\
Mean of outcome & & &
\end{tabular}


Table 8: Heterogeneous Effects of Drought Exposure in Early Childhood on Male Health Outcomes After Repeal of Legal Migration Barriers, 1987-1993

\begin{tabular}{|c|c|c|c|c|c|c|}
\hline \multirow{3}{*}{ Dependent variable: } & \multicolumn{4}{|c|}{ Sample $[N=111,553]$} & \multirow{2}{*}{\multicolumn{2}{|c|}{$\begin{array}{c}\text { Sample [N=112] } \\
\text { Log cohort size }\end{array}$}} \\
\hline & \multicolumn{2}{|c|}{ Any disability } & \multicolumn{2}{|c|}{ Num. disabilities } & & \\
\hline & $(1)$ & $(2)$ & $(3)$ & $(4)$ & $(5)$ & $(6)$ \\
\hline \multirow[t]{2}{*}{ Fraction early childhood in drought } & $0.01 * * *$ & & $0.011 * * *$ & & 0.054 & \\
\hline & $(0.004)$ & & $(0.004)$ & & $(0.052)$ & \\
\hline \multirow[t]{2}{*}{ Fraction early childhood in drought*TBVC } & -0.001 & & 0.000 & & $0.016^{*}$ & \\
\hline & $(0.002)$ & & $(0.002)$ & & $(0.007)$ & \\
\hline \multirow[t]{2}{*}{ Drought in birth year } & & $0.018 * *$ & & $0.024^{* *}$ & & $0.106^{*}$ \\
\hline & & $(0.007)$ & & $(0.007)$ & & $(0.048)$ \\
\hline \multirow[t]{2}{*}{ Drought in birth year*TBVC } & & -0.004 & & $-0.004^{*}$ & & -0.001 \\
\hline & & $(0.002)$ & & $(0.002)$ & & $(0.006)$ \\
\hline District controls*Drought measures & $\mathrm{Y}$ & $\mathrm{Y}$ & $\mathrm{Y}$ & $\mathrm{Y}$ & $\mathrm{Y}$ & $\mathrm{Y}$ \\
\hline Birth year, district FE & $\mathrm{Y}$ & $\mathrm{Y}$ & $\mathrm{Y}$ & $\mathrm{Y}$ & $\mathrm{Y}$ & $\mathrm{Y}$ \\
\hline \multicolumn{7}{|l|}{ p-values for F-tests } \\
\hline All drought parameters jointly $=0$ & 0.09 & 0.01 & 0.09 & 0.01 & 0.14 & 0.00 \\
\hline Sum of Drought and Drought $* \mathrm{TBVC}=0$ & 0.07 & 0.12 & 0.08 & 0.06 & 0.25 & 0.74 \\
\hline Mean of outcome & 0.03 & 0.03 & 0.032 & 0.032 & 6.83 & 6.83 \\
\hline \multicolumn{7}{|c|}{$\begin{array}{l}\text { Robust standard errors clustered on the year of birth. Levels of significance: } \mathrm{p}<0.01^{* * *}, \mathrm{p}<0.05^{* *}, \mathrm{p}<0.1^{*} \text {. Drought exposure is a binary variable } \\
\text { constructed using values of the Spatial Precipitation Index; fraction of infancy in drought is the fraction of years from in utero period to age } 4 \text { that } \\
\text { the drought indicator equals one ; TBVC indicates whether an individual reports a prior district is an historical TBVC area or not. Sample restricted } \\
\text { to } 1996 \text { Census data on males born between } 1987 \text { and } 1993 \text { (ages 3-9). Coefficient on fraction early childhood in drought evaluated at the mean of } \\
\text { this variable (.168). }\end{array}$} \\
\hline
\end{tabular}


Table 9: Effect of Drought in 1995 on Remittance Inflows to All Former Homelands in 1995

\begin{tabular}{|c|c|c|c|c|c|c|}
\hline \multirow[t]{3}{*}{ Dependent variable } & \multicolumn{6}{|c|}{ Any remittances received in 1995? [Mean=0.20] } \\
\hline & \multicolumn{2}{|c|}{ All households [N=222,355] } & \multicolumn{2}{|c|}{$\begin{array}{l}\text { Households in former non- } \\
\text { TBVC areas }[N=115,126]\end{array}$} & \multicolumn{2}{|c|}{$\begin{array}{c}\text { Households in former TBVC } \\
\text { areas }[N=107,229]\end{array}$} \\
\hline & $(1)$ & $(2)$ & $(3)$ & $(4)$ & $(5)$ & $(6)$ \\
\hline Drought last year & $\begin{array}{c}0.002 \\
(0.005)\end{array}$ & $\begin{array}{c}0.026 \\
(0.016)\end{array}$ & $\begin{array}{c}0.009 \\
(0.006)\end{array}$ & $\begin{array}{l}-0.003 \\
(0.030)\end{array}$ & $\begin{array}{l}-0.006 \\
(0.005)\end{array}$ & $\begin{array}{c}0.023 \\
(0.018)\end{array}$ \\
\hline Any migrant worker in $\mathrm{HH}$ ? & $\begin{array}{c}0.413 * * * \\
(0.021)\end{array}$ & $\begin{array}{c}0.406 * * * \\
(0.023)\end{array}$ & $\begin{array}{c}0.391^{* * *} \\
(0.024)\end{array}$ & $\begin{array}{c}0.389 * * * \\
(0.025)\end{array}$ & $\begin{array}{c}0.436 * * * \\
(0.036)\end{array}$ & $\begin{array}{c}0.424 * * * \\
(0.042)\end{array}$ \\
\hline Drought last year*Any migrant worker from HH? & $\begin{array}{c}0.027^{* *} \\
(0.009)\end{array}$ & $\begin{array}{c}0.028 * * * \\
(0.009)\end{array}$ & $\begin{array}{c}0.033^{* *} \\
(0.011)\end{array}$ & $\begin{array}{r}0.032 * * \\
(0.011)\end{array}$ & $\begin{array}{c}0.021 \\
(0.015)\end{array}$ & $\begin{array}{c}0.022 \\
(0.015)\end{array}$ \\
\hline Fraction of 1948-1996 period in drought & $\begin{array}{l}0.036^{* *} \\
(0.014)\end{array}$ & $\begin{array}{c}0.048 * * * \\
(0.013)\end{array}$ & $\begin{array}{c}0.029 \\
(0.020)\end{array}$ & $\begin{array}{l}0.037 * \\
(0.017)\end{array}$ & $\begin{array}{c}0.049 \\
(0.024)\end{array}$ & $\begin{array}{l}0.062 * * * \\
(0.011)\end{array}$ \\
\hline $\begin{array}{l}\text { District variables*Drought last year controls } \\
\text { p-value for } \boldsymbol{F} \text {-test }\end{array}$ & $\mathrm{N}$ & $\mathrm{Y}$ & $\mathrm{N}$ & $\mathrm{Y}$ & $\mathrm{N}$ & $\mathrm{Y}$ \\
\hline Sum of Drought and Drought*Migrant $=0$ & 0.00 & 0.01 & 0.00 & 0.41 & 0.31 & 0.14 \\
\hline
\end{tabular}


Appendix Table 1: Simulating stocks of migrant networks

\begin{tabular}{|c|c|c|c|}
\hline \multicolumn{4}{|c|}{ Panel A: Assumptions } \\
\hline Variable & Value & Source & Details \\
\hline Adult population in a representative homeland district & 12,000 & Census 1996 & Own calculations \\
\hline 1+Annual adult African population growth rate & 1.0225 & Simkins 2011 & Population growth 1904-1996 \\
\hline Average African household size & 5 & Simkins 2011 & Calculated in the mid-1960s \\
\hline Mean adults/household & 2.5 & Simkins 2011 & Estimate from household structure \\
\hline Annual adult outmigration rate, non-TBVC areas & $0.25 \%$ & Census 1996 & Own calculations, Table 1 \\
\hline Annual adult outmigration rate, TBVC areas & $0.21 \%$ & Census 1996 & Own calculations, Table 1 \\
\hline
\end{tabular}

Panel B: Simulations

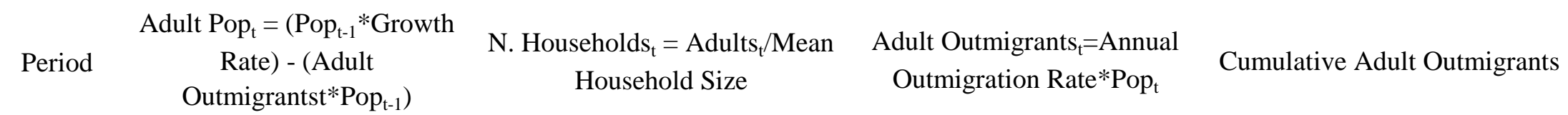

\begin{tabular}{|c|c|c|c|c|c|c|c|c|}
\hline Area & Non-TBVC & TBVC & Non-TBVC & TBVC & Non-TBVC & TBVC & Non-TBVC & TBVC \\
\hline $\mathrm{t}=1$ & $12,000.0$ & $12,000.0$ & $4,800.0$ & $4,800.0$ & 30.6 & 25.8 & 30.6 & 25.8 \\
\hline 2 & $12,239.4$ & $12,244.2$ & $4,895.8$ & $4,897.7$ & 31.2 & 26.3 & 61.7 & 52.0 \\
\hline 3 & $12,483.7$ & $12,493.5$ & $4,993.5$ & $4,997.4$ & 31.8 & 26.8 & 93.5 & 78.8 \\
\hline 4 & $12,732.8$ & $12,747.8$ & $5,093.1$ & $5,099.1$ & 32.4 & 27.4 & 125.9 & 106.2 \\
\hline 5 & $12,986.8$ & $13,007.2$ & $5,194.7$ & $5,202.9$ & 33.1 & 27.9 & 159.0 & 134.1 \\
\hline $6 \ldots$ &.. &.. & .. & .. & .. & .. & .. & .. \\
\hline $\mathrm{T}=39$ & $25,423.7$ & $25,805.7$ & $10,169.5$ & $10,322.3$ & 64.7 & 55.4 & $1,777.8$ & $1,510.9$ \\
\hline
\end{tabular}

\begin{tabular}{lcc}
\multicolumn{4}{c}{ Panel C: Stock of migrants associated with households at end of period } \\
\cline { 2 - 3 } & Non-TBVC & TBVC \\
\hline Cumulative number of outmigrants per adult population & 0.070 & 0.059 \\
Share of households with a migrant: Assm 1 migrant per household & 0.175 & 0.146 \\
Share of households with a migrant: Assm 1.5 migrants per household & 0.117 & 0.098 \\
\hline
\end{tabular}

Notes: This table presents results of a simulation exercise that shows how low initial levels of annual adult outmigration, and small differences in these levels across areas, can cumulate to much larger differences in share of households with migrants over a 39 year period. Panel B shows estimated number of outmigrants per year in a representative ex-homeland district using the set of assumptions set out in Panel A. Panel C reports cumulative total migrants for this district and by number of households in the district. 
Appendix Table 2: Heterogeneous Effects of Drought Exposure in Early Childhood on Components of Male Disabilities

\begin{tabular}{|c|c|c|c|c|c|c|c|c|}
\hline \multirow[t]{2}{*}{ Dependent variable: } & \multicolumn{4}{|c|}{ Sight disability [Mean=0.02] } & \multicolumn{4}{|c|}{ Physical disability [Mean=0.01] } \\
\hline & $(1)$ & $(2)$ & $(3)$ & (4) & $(5)$ & $(6)$ & $(7)$ & $(8)$ \\
\hline Fraction early childhood in drought & $\begin{array}{l}0.001^{*} \\
(0.000)\end{array}$ & & $\begin{array}{l}0.002^{*} \\
(0.001)\end{array}$ & & $\begin{array}{l}0.001^{*} \\
(0.000)\end{array}$ & & $\begin{array}{c}0.002^{* *} \\
(0.001)\end{array}$ & \\
\hline Fraction early childhood in drought*TBVC & $\begin{array}{c}0.000 \\
(0.000)\end{array}$ & & $\begin{array}{c}0.001 \\
(0.000)\end{array}$ & & $\begin{array}{c}0.001^{* * *} \\
(0.000)\end{array}$ & & $\begin{array}{r}0.002^{* * *} \\
(0.000)\end{array}$ & \\
\hline Drought in birth year & & $\begin{array}{c}0.001 \\
(0.002)\end{array}$ & & $\begin{array}{c}0.006 \\
(0.005)\end{array}$ & & $\begin{array}{l}-0.001 \\
(0.002)\end{array}$ & & $\begin{array}{l}-0.007 \\
(0.004)\end{array}$ \\
\hline Drought in birth year*TBVC & & $\begin{array}{l}0.0042 * \\
(0.002)\end{array}$ & & $\begin{array}{c}0.005^{* *} \\
(0.002)\end{array}$ & & $\begin{array}{c}0.0032 * \\
(0.002)\end{array}$ & & $\begin{array}{c}0.002 \\
(0.002)\end{array}$ \\
\hline \multicolumn{9}{|l|}{ p-values for F-tests } \\
\hline All drought parameters jointly $=0$ & 0.05 & 0.04 & 0.24 & 0.08 & 0.00 & 0.11 & 0.00 & 0.04 \\
\hline Sum of Drought and Drought $*$ TBVC $=0$ & 0.02 & 0.01 & 0.13 & 0.08 & 0.00 & 0.10 & 0.00 & 0.49 \\
\hline Birth year, district FE & $\mathrm{Y}$ & $\mathrm{Y}$ & $\mathrm{Y}$ & $\mathrm{Y}$ & $\mathrm{Y}$ & $\mathrm{Y}$ & $\mathrm{Y}$ & $\mathrm{Y}$ \\
\hline District variables*Drought controls & $\mathrm{N}$ & $\mathrm{N}$ & $\mathrm{Y}$ & $\mathrm{Y}$ & $\mathrm{N}$ & $\mathrm{N}$ & $\mathrm{Y}$ & $\mathrm{Y}$ \\
\hline \multirow[t]{2}{*}{ Dependent variable: } & \multicolumn{4}{|c|}{ Hearing/speech disability [Mean=0.01] } & \multicolumn{4}{|c|}{ Mental disability [Mean=0.01] } \\
\hline & $(1)$ & $(2)$ & (3) & $(4)$ & (5) & $(6)$ & $(7)$ & $(8)$ \\
\hline Fraction early childhood in drought & $\begin{array}{l}0.0004 \\
(0.000)\end{array}$ & & $\begin{array}{l}0.0004 \\
(0.001)\end{array}$ & & $\begin{array}{l}0.0003 \\
(0.000)\end{array}$ & & $\begin{array}{l}0.0013 \\
(0.001)\end{array}$ & \\
\hline Fraction early childhood in drought*TBVC & $\begin{array}{l}0.0002 \\
(0.000)\end{array}$ & & $\begin{array}{l}0.0004 \\
(0.000)\end{array}$ & & $\begin{array}{l}0.0001 \\
(0.000)\end{array}$ & & $\begin{array}{l}0.0004 \\
(0.000)\end{array}$ & \\
\hline Drought in birth year & & $\begin{array}{c}0.000 \\
(0.001)\end{array}$ & & $\begin{array}{l}-0.006 \\
(0.006)\end{array}$ & & $\begin{array}{c}0.000 \\
(0.001)\end{array}$ & & $\begin{array}{c}-0.004 \\
(0.007)\end{array}$ \\
\hline Drought in birth year*TBVC & & $\begin{array}{c}0.001 \\
(0.001)\end{array}$ & & $\begin{array}{c}0.000 \\
(0.002)\end{array}$ & & $\begin{array}{c}0.001 \\
(0.002)\end{array}$ & & $\begin{array}{c}0.001 \\
(0.002)\end{array}$ \\
\hline \multicolumn{9}{|l|}{ p-values for F-tests } \\
\hline All drought parameters jointly $=0$ & 0.02 & 0.56 & 0.38 & 0.24 & 0.10 & 0.68 & 0.39 & 0.75 \\
\hline Sum of Drought and Drought $*$ TBVC $=0$ & 0.01 & 0.29 & 0.39 & 0.45 & 0.05 & 0.38 & 0.18 & 0.75 \\
\hline Birth year, district FE & $\mathrm{Y}$ & $\mathrm{Y}$ & $\mathrm{Y}$ & $\mathrm{Y}$ & $\mathrm{Y}$ & $\mathrm{Y}$ & $\mathrm{Y}$ & $\mathrm{Y}$ \\
\hline District variables*Drought controls & $\mathrm{N}$ & $\mathrm{N}$ & $\mathrm{Y}$ & $\mathrm{Y}$ & $\mathrm{N}$ & $\mathrm{N}$ & Y & Y \\
\hline
\end{tabular}


Appendix Table 3: Summary Statistics for TBVC and Non-TBVC Areas for Placebo sample

\begin{tabular}{|c|c|c|c|c|c|c|c|c|}
\hline & $\begin{array}{c}\text { Sample means } \\
\text { for all } \\
\text { homelands }\end{array}$ & $\begin{array}{c}\text { TBVC } \\
\text { sample } \\
\text { means }\end{array}$ & $\begin{array}{c}\text { Non-TBVC } \\
\text { sample means }\end{array}$ & diff & $\begin{array}{l}p \text {-value of } \\
\text { difference }\end{array}$ & $\mathrm{N}$ & Min. & Max. \\
\hline \multicolumn{9}{|c|}{ Panel A: Individual-level data } \\
\hline \multicolumn{9}{|l|}{ Cohorts born 1987-1993 } \\
\hline Drought in birth year & 0.116 & 0.132 & 0.099 & 0.032 & 0.351 & 225,515 & 0 & 1 \\
\hline Fraction of infancy (in utero to age 4) in drought & 0.167 & 0.187 & 0.145 & 0.043 & 0.001 & 225,515 & 0 & 0.4 \\
\hline Age & 5.990 & 5.986 & 5.995 & -0.009 & 0.198 & 225,515 & 3 & 9 \\
\hline Female & 0.502 & 0.503 & 0.500 & 0.002 & 0.246 & 225,515 & 0 & 1 \\
\hline Any serious disability & 0.029 & 0.030 & 0.027 & 0.004 & 0.006 & 223,829 & 0 & 1 \\
\hline Number of serious disabilities & 0.030 & 0.032 & 0.029 & 0.003 & 0.012 & 223,829 & 0 & 4 \\
\hline Sight disability & 0.012 & 0.013 & 0.011 & 0.002 & 0.029 & 223,829 & 0 & 1 \\
\hline Speech/hearing disability & 0.011 & 0.011 & 0.010 & 0.002 & 0.043 & 223,829 & 0 & 1 \\
\hline Physical disability & 0.006 & 0.006 & 0.006 & 0.0001 & 0.665 & 223,829 & 0 & 1 \\
\hline Mental disability & 0.002 & 0.002 & 0.002 & -0.0001 & 0.619 & 223,829 & 0 & 1 \\
\hline Number of districts & 16 & 6 & 10 & & & & & \\
\hline Number of birth years & 6 & 6 & 6 & & & & & \\
\hline
\end{tabular}

Individual and district-level means for African respondents in the 1996 Census, 10\% sample. TBVC stands for Transkei, Boputhatswana, Venda and Ciskei, the four earliest


are currently or previously living in any districts formerly part of a homeland. $p$-values from regressions of each variable on a TBVC indicator, clustered on year of birth. 
Appendix Table 4: Response of Crop Yields to Drought in TBVC and Non-TBVC Areas

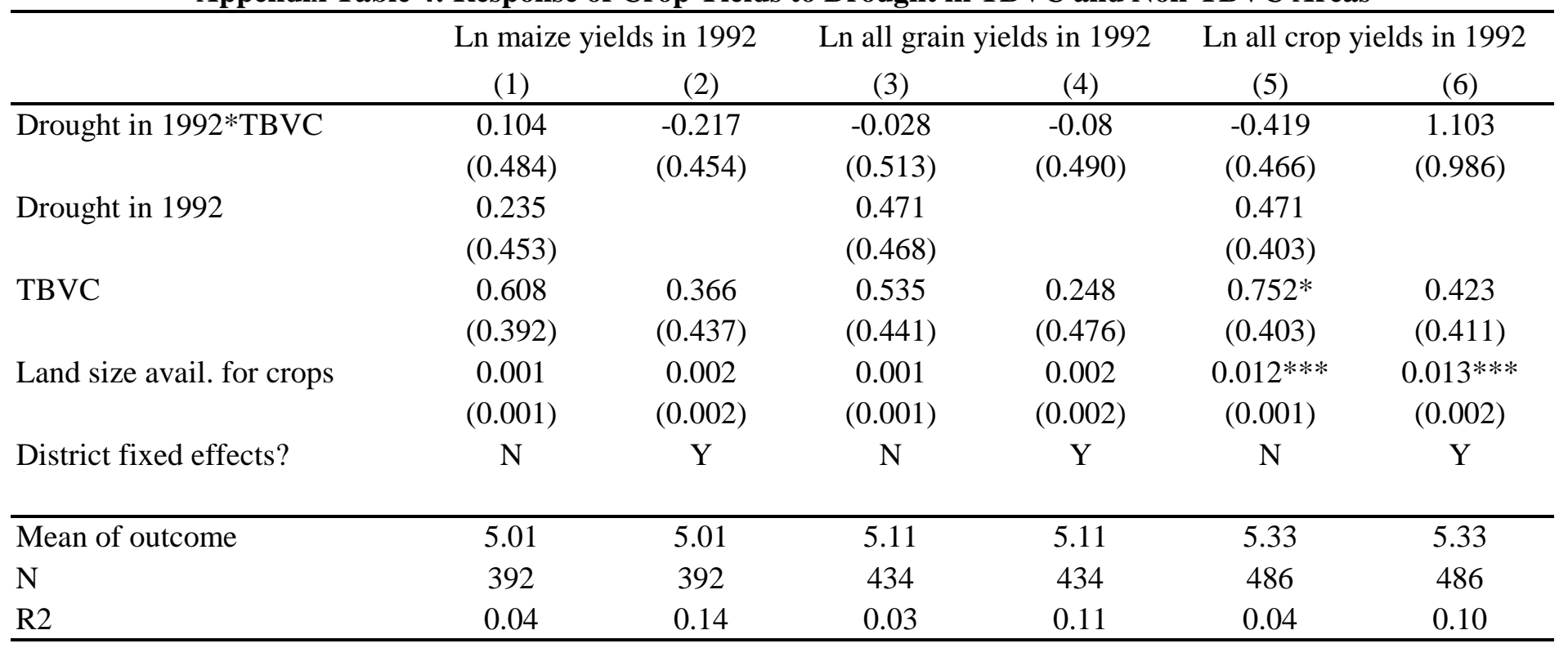

Unit of observation is the household. Outcome is the natural log of the physical quantity (kilograms) of output of maize alone, all grains combined (maize, sorghum and wheat) and all crops combined. Sample includes African households in ex-homeland districts from 1993 Project on Standards of Living in South Africa who report doing any agriculture in the year before the survey. Results are weighted using census weights. $\mathrm{p}<0.01^{* * *}, \mathrm{p}<0.05^{*}, \mathrm{p}<0.1^{*}$ 